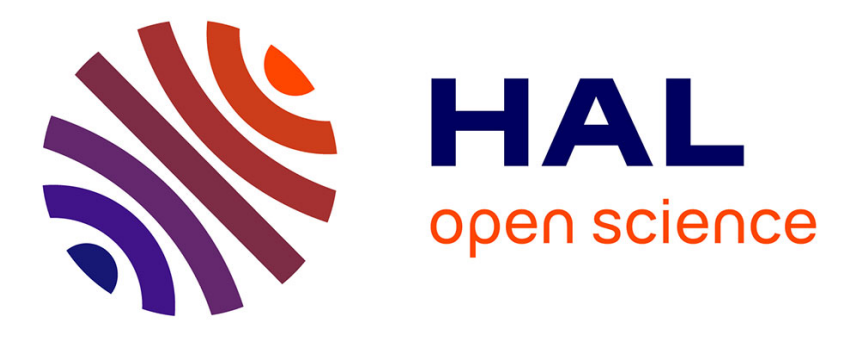

\title{
Emplacement of metamorphic core complexes and associated geothermal systems controlled by slab dynamics
}

\author{
Vincent Roche, Pietro Sternai, Laurent Guillou-Frottier, Armel Menant, \\ Laurent Jolivet, Vincent Bouchot, Taras Gerya
}

\section{To cite this version:}

Vincent Roche, Pietro Sternai, Laurent Guillou-Frottier, Armel Menant, Laurent Jolivet, et al.. Emplacement of metamorphic core complexes and associated geothermal systems controlled by slab dynamics. Earth and Planetary Science Letters, 2018, 498, pp.322-333. 10.1016/j.epsl.2018.06.043 . insu-01856826

\section{HAL Id: insu-01856826 \\ https://hal-insu.archives-ouvertes.fr/insu-01856826}

Submitted on 14 Aug 2018

HAL is a multi-disciplinary open access archive for the deposit and dissemination of scientific research documents, whether they are published or not. The documents may come from teaching and research institutions in France or abroad, or from public or private research centers.
L'archive ouverte pluridisciplinaire HAL, est destinée au dépôt et à la diffusion de documents scientifiques de niveau recherche, publiés ou non, émanant des établissements d'enseignement et de recherche français ou étrangers, des laboratoires publics ou privés. 
Earth and Planetary Science Letters

2 Volume 498, 15 September 2018, Pages 322-333

Emplacement of metamorphic core complexes and associated geothermal systems controlled by slab dynamics

VincentRoche ${ }^{\text {abc }}$

PietroSternai ${ }^{\mathrm{d}}$

LaurentGuillou-Frottier ${ }^{\text {cab }}$

10 ArmelMenant $^{\mathrm{e}}$

11 LaurentJolivet $^{\mathrm{f}}$

12 VincentBouchot ${ }^{\mathrm{cab}}$

13 TarasGerya $^{\mathrm{g}}$

14 a

\section{3 https://doi.org/10.1016/j.eps1.2018.06.043}

\section{ABSTRACT}

Slab rollback results in the development of low-angle normal faults (detachments) and

37 metamorphic core complexes (MCCs) in back-arc domains. Although the mechanical

38 consequences of slab dynamics on lithospheric and crustal behaviors have already been studied, 
39 thermal effects have not been investigated yet. This study shows that slab rollback produces

40 lithospheric-scale thermal perturbations intrinsically associated with emplacement of amagmatic

41 high-enthalpy geothermal systems. Using a multi-scale numerical modeling approach, with

42 lithospheric-scale 3-D thermo-mechanical models of subduction, and 2-D models of fluid flow

43 at the scale of detachments, we demonstrate that subduction-induced extensional tectonics

44 controls the genesis and distribution of crustal-scale thermal domes from the base of the crust,

45 and the location of high-energy geothermal systems. We find that when slab tearing occurs, Moho

46 temperatures can temporarily increase by up to $250{ }^{\circ} \mathrm{C}$ due to significant shear heating in the

47 flowing upper mantle. Associated thermal anomalies (with characteristic width and spacing of

48 tens and hundreds of $\mathrm{km}$, for crustal and lithospheric scales, respectively) then migrate

49 systematically toward the retreating trench. These thermal domes weaken the crust, localize

50 deformation and enhance the development of crustal-scale detachments. These thermo-

51 mechanical instabilities mimic genesis of high-temperature MCCs with migmatitic cores in the

52 back-arc domain, such as those of the Menderes (western Anatolia, Turkey) and Larderello

53 (southern Tuscany) provinces in the Mediterranean realm, and those in the Basin and Range

54 (western United States), where detachments control the bulk of the heat transport. At the scale of

55 MCCs, the bulk fluid flow pattern is controlled by topography-driven flow while buoyancy-

56 driven flow dominates within the permeable detachments, focusing reservoir location of high-

57 energy geothermal systems at shallow depth beneath the detachments.

59 1. INTRODUCTION

60 The development of geothermal power plants has been increasing since the 1970s, 61 building upon more than 100 years of history in geothermal energy extraction. Currently, the 
62 installed global capacity is estimated at $12.6 \mathrm{GWe}$ (Gigawatt electrical), and forecasts for 2050

63 point to a worldwide capacity of $140 \mathrm{GWe}$, approximately $8.3 \%$ of total world electricity

64 production (Bertani, 2016). Many of the high enthalpy geothermal resources (HEGRs) that make

65 such an ambitious goal possible are located in the vicinity of subduction zones and volcanic arcs,

66 where both magmatic and tectonic processes operate (Fig. 1). Others are located in "amagmatic"

67 provinces such as the Menderes Massif in Western Turkey and the Basin and Range in the

68 Western United States. Particularly noteworthy for this study is that while geothermal systems

69 associated with magmatism have been studied in detail (e.g. Cumming, 2009) those located in

70 "amagmatic" provinces have received less attention (Moeck et al., 2014; Roche et al. submitted).

71 Recent to present (i.e. Pliocene-Quaternary) magmatism in the upper crust across the

72 Menderes Massif and the Basin and Range is rare (Blackwell et al., 2009; Faulds et al., 2010)

73 compared to that of the Larderello geothermal field, located in the southern Tuscany (i.e. Italy)

74 (Santilano et al., 2015) (Fig. 1). Open discussions on the possible role of hidden magmatic

75 intrusions on these geothermal systems remains debated. Even if present, however, magmatic

76 intrusions alone cannot explain the extent of these geothermal provinces (several thousand $\mathrm{km}^{2}$

77 each), and therefore cannot account for high concentration of HEGRs. We must thus identify

78 other sources of heat (deeper and larger-scale) possibly associated with deep, large-scale

79 geodynamic processes involved by the nearby subduction systems. 


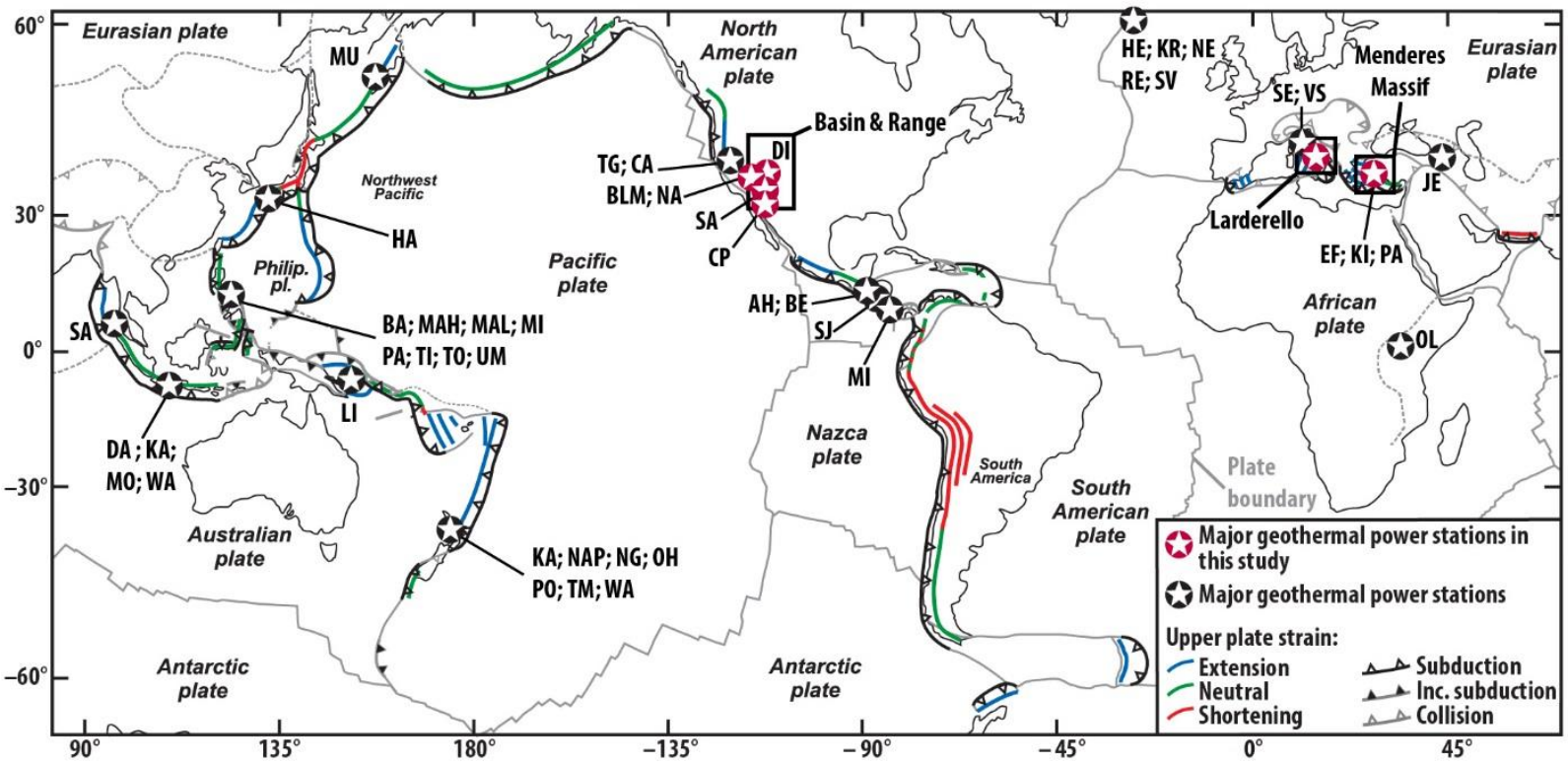

82 Figure 1: The major subduction zones on Earth (modified from Schellart et al. 2007). Black stars

83 show the locations of major geothermal power stations that are larger than $50 \mathrm{MWe}$ that are

84 currently operational or under construction. Red stars are reserved for highlighting those within

85 the study areas mentioned in this study. Geothermal stations: JE, Jermaghbyur (Armenia); Mi,

86 Miravalles (Costa Rica); AH, Ahuachapán, BE, Berlín (El Salvador); HE, Hellisheidi, KR,

87 Krafla, NE, Nesjavellir, RE, Reykjanes, SV, Svartsengi (Iceland); DA, Darajat, KA, Kamojang,

88 MO, Mount Salak, SA, Sarulla, WA, Wayang Windu (Indonesia); LA, Larderello, SE,

89 Serrazzano, VS, Valle Secolo (Italy); HA, Hatchobaru (Japan); OL, Olkaria (Kenya); CP, Cerro

90 Prieto (Mexico); KA, Kawerau, NAP, Nga Awa Purua, NG, Ngatamariki, OH, Ohaaki, PO,

91 Poihipi, TM, Te Mihi, WA, Wairakei (New Zealand); SJ, San Jacinto Tizate (Nicaragua); LI,

92 Linhir (Papua New Guinea); BA, Bacman I, MAH, Mahanagdong, MAL, Malitbog, MI,

93 Mindanao I-II, PA, Palinpinon I-II, TI, Tiwi A-B-C, TO, Tongonan 1, UM, Upper Mahiao

94 (Philippines); MU, Mutnovskaya, Russia; EF, Efeler, KI, Kızıldere, PA, Pamukören (Turkey);

95 BLM, CA, Calistoga, DV, Dixie Valley, NA, Navy, SA, Salton Sea, TG, The Geysers (United

96 States).

Slab rollback induces lithospheric extension in the overriding plate where low-angle

99 normal faults (detachments) control both the exhumation of metamorphic core complexes

100 (MCCs) and the magma ascent and/or fluid circulation (e.g. Reynolds and Lister, 1987; Huet et 
101 al., 2011). Because detachments may correspond to permeable structures deeply rooted down to 102 the brittle-ductile transition (Famin et al., 2004; Mezri et al., 2015), active extensional domains 103 in back-arc regions could represent favorable settings for HEGRs. The possible sources of heat 104 responsible for regional high temperature-low pressure (HT-LP) metamorphic overprint recorded 105 in these MCCs include (i) heating associated with thermal diffusion of excess heat generated by 106 nappe stacking (increased radiogenic crustal heat, e.g. Bousquet et al., 1997), (ii) shear-heating 107 in the mantle (e.g. Schubert and Yuen, 1978), or (iii) advection of hot asthenosphere to shallow 108 depths during slab retreat (Wannamaker et al., 2008; Jolivet et al., 2015). However, no unifying 109 mechanism responsible for both the generation of MCCs and emplacement of high-enthalpy 110 geothermal systems in the same regions has yet been recognized. This is however a crucial 111 question since HEGRs represent a major economic interest in terms of exploration for carbon112 free energy resources.

113 Here, we first document the self-consistent formation of crustal domes in the overriding 114 plate as a result of thermo-mechanical instabilities in 3-D numerical simulations of ocean115 continent subduction dynamics. These models provide crucial thermal constraints for the mantle 116 and crust, and show the importance of shear heating and fast mantle flow on the overall heat 117 budget. Subduction-induced thermal signature in the overriding crust obtained from these 118 experiments is then used as basal thermal boundary condition in 2-D numerical models dedicated 119 to the understanding of fluid flow in the upper crust in presence of detachments that accommodate 120 the formation of these domes. Results show that deep upper crustal hot fluids are drained upward 121 by the permeable detachment. These results will be first compared with geological observations 122 from the Menderes Massif, and then in the discussion, with other cases in the Mediterranean 123 realm (Anatolia and Tuscany) and in the western United States. 
During the Cenozoic, the eastern Mediterranean region (Figs. 2a and 2b) has undergone

127 a two-step tectono-metamorphic evolution. In the late Cretaceous-Eocene, the convergence of

128 Africa and Eurasia first led to the closure of the Izmir-Ankara Ocean. At this time, the accretion

129 of subducting continental and oceanic tectonic units (e.g. Jolivet and Brun, 2010) led toformation

130 of a south-verging crustal-scale orogenic wedge. Since the Oligo-Miocene, collapse of the

131 Hellenides-Taurides belt in this region is mainly controlled by the southward retreat of the

132 African slab, further accelerated in the middle Miocene by a major slab tearing event evidenced

133 by tomographic models below western Turkey (Fig. 2c) (e.g. Piromallo and Morelli, 2003).

134 Extension in the overriding plate has thus led to exhumation of different MCCs such as the

135 Cyclades in the Aegean Sea and the Menderes Massif in western Anatolia, accommodated by

136 crustal-scale low-angle normal faults such as the Simav, Alaşehir and Büyük Menderes

137 detachments (Hetzel et al., 1995; Bozkurt et al., 2011) (Figs. 2b and 2c). Currently, plate

138 kinematics in this region are characterized by more localized extension, mainly controlled by the

139 westward motion of Anatolia (Reilinger et al., 2006) and by N-S extension accommodated by

140 steep normal faults in the Gediz and Büyük Menderes Grabens, both consequences of slab

141 dynamics (e.g. Jolivet et al. 2013; Gessner et al., 2013; Sternai et al., 2014). 

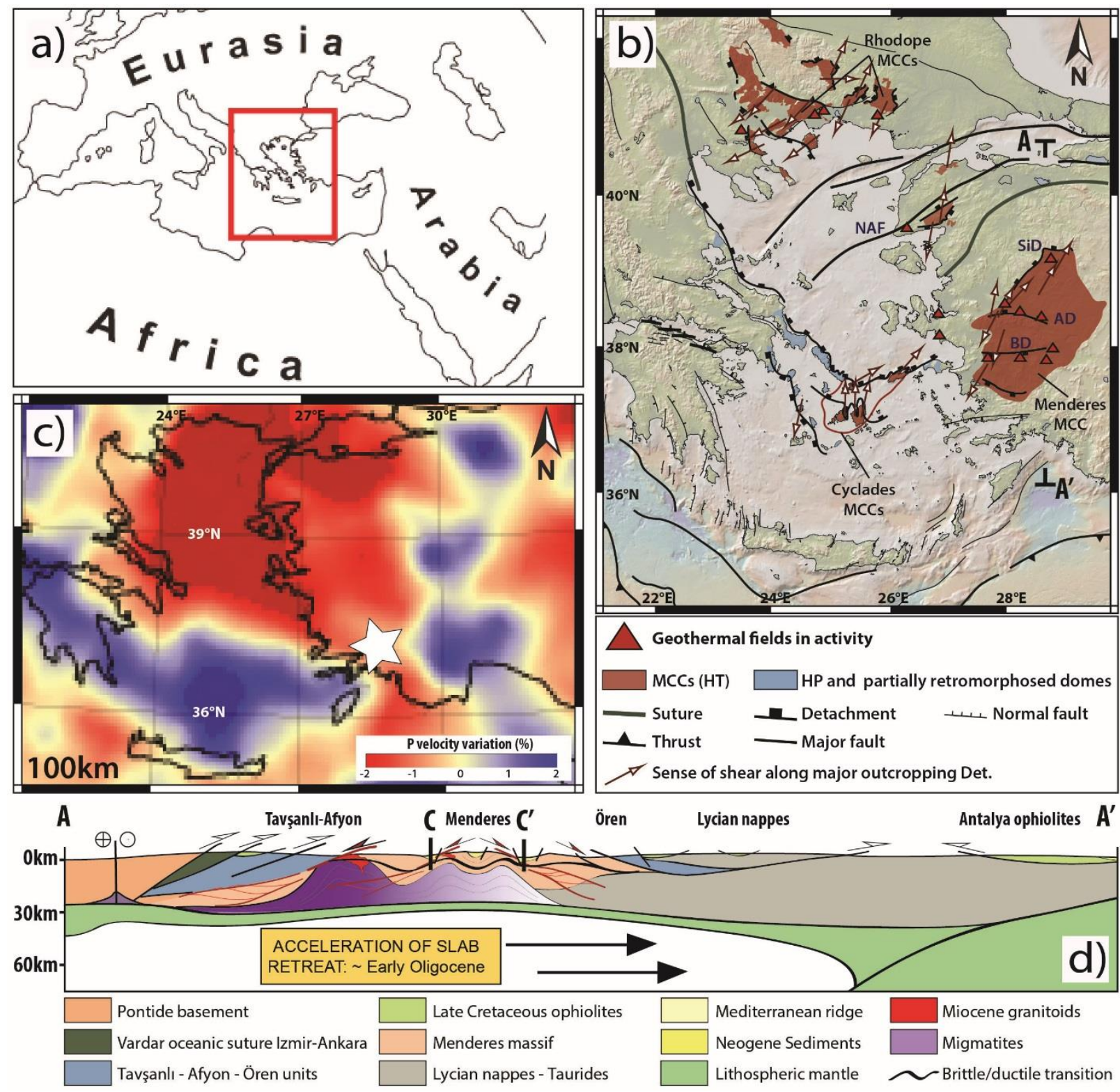

Figure 2: (a) Global map with red box showing the location on the study area. (b) Simplified

144 tectonic maps showing the main metamorphic core complexes and associated detachments faults

145 in the Aegean region (modified from Jolivet et al., (2015)). SiD: Simav Detachment, AD:

146 Alaşehir Detachment, BD: Büyük Detachment, NAF: North Anatolian Fault. (c) Tomographic

147 models from Piromallo and Morelli (2003) showing the Vp anomalies at the $100 \mathrm{~km}$ depth. White

148 star shows the location of a slab tear below the Menderes Massif. (d) Simplified cross-sections

149 highlighting slab retreat and formation of crustal detachments. CC' corresponds to the 2-D

150 numerical model cross-section. 
153 Appendix 1). This region is characterized by long wavelength east-west variations of surface heat

154 flow density with values locally exceeding $90 \mathrm{~mW} \mathrm{~m}^{-2}$ (Erkan, 2015). At depth, it seems that a 155 similar east-west long wavelength thermal anomaly is also present, as suggested by the Curie156 point isotherm map of Aydin et al. (2005). According to these authors, the depth of the $580{ }^{\circ} \mathrm{C}$ 157 isotherm would be lower than $10 \mathrm{~km}$ in western Anatolia (see Fig. S1b in Appendix 1). It turns 158 out that most of the geothermal systems in Turkey are located in the Menderes Massif (Fig. 2b) 159 where recent magmatism is almost absent. Here, geothermal fields are characterized by medium160 to high-enthalpy, with reservoir temperature values ranging from 120 to $287^{\circ} \mathrm{C}$ (e.g. Roche et al. 161 in revision). Most are used for district heating systems (e.g. Balçova and Salihli), whereas a few 162 are exploited for electricity production (e.g. Germencik, Salavatli; Kızıldere; Alaşehir). Some 163 authors have suggested that most of the geothermal activity can be considered as amagmatic in 164 origin (Faulds et al., 2010; Gessner et al., 2017). However, Ozdemir et al. (2017) considered a 165 probable magmatic intrusion in the crust to explain the heat source. Since there is presently no 166 evidence for the existence of such plutons, some authors suggest a deeper and larger heat source 167 triggered by large-scale tectonic processes such as subduction (Kaya, 2015; Gessner et al., 2017; 168 Roche et al., submitted). In that sense, Kaya (2015) invoked a possible lithospheric thinning as 169 the origin of the anomalously high heat flow. This example show that large-scale processes 170 related to lithosphere dynamics could be involved in the genesis of geothermal systems. We thus 171 need to employ a multi-scale approach (lithospheric- and crustal-scales), to improve the 172 characterization of heat transfer possesses from the mantle to the geothermal system. 
In a previous study dedicated to the analysis of surface deformation in the Aegean-

176 Anatolian domain, Sternai et al. (2014) found that mantle flow due to slab rollback and tearing

177 can drag the upper plate from below, and explain upper plate extension and the formation of the

178 North Anatolian Fault. Their results emphasize the active role of mantle flow in driving the

179 surface strain and horizontal crustal velocities. However, the associated thermal processes were

180 not described by these authors. Because heat transport is inherently coupled with deformation,

181 mantle shearing may provide a strong heat source. Thus, we must consider it, especially if we

182 want to describe in detail the thermal features associated with 3-D subduction dynamics when

183 slab rollback and tearing occur. Indeed, while radioactive heat production is considered as the

184 main heat source in the continental crust, shear heating has been suggested to be important in the 185 mantle (Shubert and Yuen, 1978) and thus probably also in arc and back-arc settings where fast 186 slab dynamics may be associated with intense asthenospheric flow. Here, we perform similar 187 numerical simulations than Sternai et al. (2014), but improve the analysis by investigating the 188 effects of shear heating. We describe the numerical results from a thermal point of view, by 189 focusing on the localization of crustal thermal anomalies in the overriding plate.

\subsection{Model setup}

The numerical simulations were performed with the code "I3ELVIS" (Gerya, 2010) that

193 solves the momentum, continuity and energy equations based on a staggered finite difference

194 scheme combined with a marker-in-cell technique. Realistic, non-Newtonian visco-plastic

195 rheologies are used in the model, and includes temperature- and pressure-dependent viscosities

196 (see Appendix 2). The model setup is shown in Figure 3. The model domain measures 

$2000 \times 328 \times 1000 \mathrm{~km}$ in the $\mathrm{x}, \mathrm{y}$ and $\mathrm{z}$ dimensions, respectively and is resolved by $198501 \times 165 \times 197$ grid points resulting in a resolution of 4, 2 and $5 \mathrm{~km}$ in the $\mathrm{x}, \mathrm{y}$ and $\mathrm{z}$ dimensions, 199 respectively. It includes three continental plates (C1, C2 and C3), allowing reproduction of 200 similar tectonic events that affected the Tethys convergent domains (subduction, collision, slab 201 tearing, trench retreat; Sternai et al. 2014). These three continental plates are defined by a crust 202 of $35 \mathrm{~km}, 50 \mathrm{~km}$ and $45 \mathrm{~km}$ thick (Fig. 3). In addition to the trench-parallel weak fracture zone 203 allowing for subduction initiation, the model includes a trench perpendicular weak fracture zone 204 within the oceanic domain, which allows for slab tearing (Fig. 3).
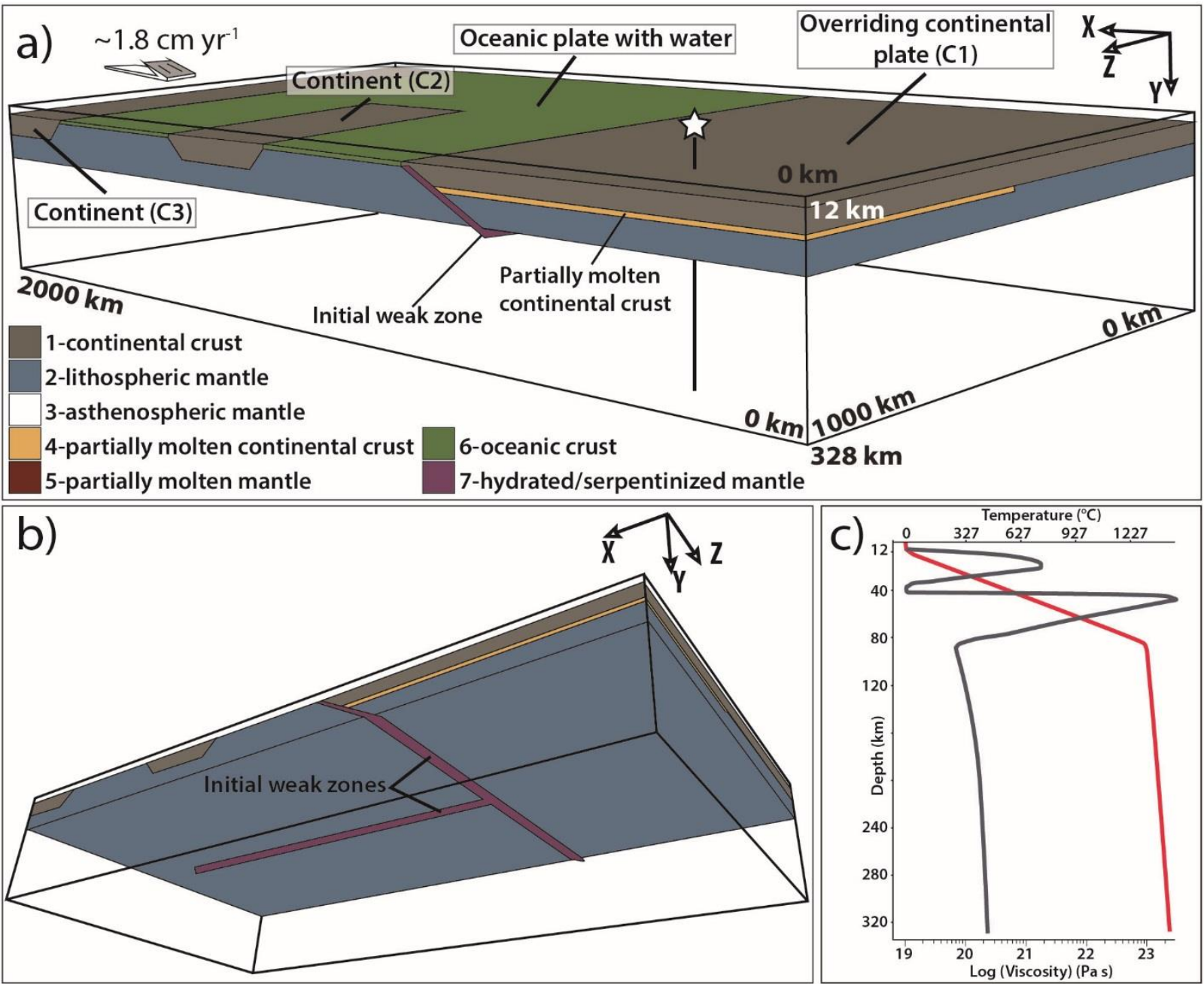

206 Figure 3: Numerical setup. (a) 3D initial model setup where the top layer ("sticky air", y $<12$ 207 km") and the water are cut off for clarity. Colours showing different rock types. (b) Location of 
208 the "weak zones" (i.e. hydrated/serpentinized mantle) into the lithosphere to trigger subduction 209 (z-parallel) and to allow slab tearing (x-parallel) in the initial model. (c) Initial vertical profiles

210 of viscosity (grey) and temperature (red), taken at the location shown by the white star.

212 The initial thermal structure of $\mathrm{C} 1, \mathrm{C} 2$ and $\mathrm{C} 3$ is laterally uniform with $0{ }^{\circ} \mathrm{C}$ at the surface

213 and $1300^{\circ} \mathrm{C}$ at 90,140 and $150 \mathrm{~km}$ depth, respectively. The initial thermal structure of the oceanic

214 lithosphere corresponds to the cooling age of $120 \mathrm{Ma}$ (e.g. Turcotte and Schubert 2002). The

215 initial temperature gradient in the asthenospheric mantle is $\sim 0.5^{\circ} \mathrm{C} \mathrm{km}^{-1}$ (adiabatic). Boundary

216 conditions involve free slip on the $\mathrm{z}=0$ and $\mathrm{z}=1000 \mathrm{~km}$ sides of the model domain, while

217 uniform and constant $\mathrm{x}$-parallel velocities equal to $\sim 1.8 \mathrm{~cm} \mathrm{yr}^{-1}$ (convergence) are imposed at

218 the $x=2000 \mathrm{~km}$ boundary, and the $\mathrm{x}=0 \mathrm{~km}$ is fixed. Global mass conservation is ensured by

219 material outflow through the permeable lower boundary $(y=328 \mathrm{~km})$. Surface processes are also

220 implemented using a highly simplified gross-scale erosion-sedimentation law. The parametric

221 study on various boundary conditions and parameters is presented in Sternai et al. (2014).

222 Heat production by viscous or plastic shearing $\left(H_{s}\right)$, consisting of the dissipation of the

223 mechanical energy during irreversible non-elastic deformation, is controlled by the deviatoric

224 stresses $\sigma_{i j}^{\prime}$ and strain rates $\dot{\varepsilon}_{i j}^{\prime}$, as follow (Gerya, 2010):

$225 H_{s}=\sigma_{i j}^{\prime} \dot{\varepsilon}_{i j}^{\prime}$

226 The possibility to investigate $H_{s}$ in our numerical simulations is a significant advance with respect

227 to the previous models presented in Sternai et al. (2014). In order to test the possibility that slab

228 tearing would enhance mantle shear heating, two series of numerical models, with and without

229 slab tearing, have been performed, all other settings being equal (i.e. same boundary conditions,

230 material properties, see more information in Appendix 2). 


\subsection{Results}

233 Before focusing on thermal effects associated with slab dynamics, we briefly present the

234 model evolution. The overall sequence of events is robust and includes first an early subduction

235 of the oceanic domain between $\mathrm{C} 1$ and $\mathrm{C} 2$ with localized extensional deformation in the

236 overriding plate. In our models, it includes the magmatic arc and the back-arc domain (see video

237 S1 in Appendix 1). During this first subduction event, a toroidal mantle flow occurs below C1,

238 as induced by the down-going slab. This event also controls crustal flow and surface

239 deformation. Afterward, continental collision between C1 and C2 occurs, locally increasing slab

240 dip and thus favoring slab tearing. Later subduction of the oceanic domain between C1 and C3

241 induces widespread extensional deformation in the overriding plate. This last event is highly

242 conditioned by the previous horizontal to sub-horizontal return flow of hot asthenosphere, which

243 warms up the incipiently subducting lithosphere close to the slab tear, enhancing here a non-

244 cylindrical (i.e. not parallel to the initial upper plate margin) slab rollback. Rheological

245 stratification of the upper plate is characterized at this stage by a thin rigid lithospheric mantle

$246(\sim 10 \mathrm{~km})$. Deformation is localized in the overriding plate with strike-slip deformation

247 propagating toward the subducting plate (Sternai et al., 2014).

\subsubsection{Thermo-mechanical instabilities}

250 The early subduction event is characterized by the development of several positive 251 thermal anomalies (i.e. anomalously high temperatures) (i) at the base of the crust with 252 wavelengths around $200 \mathrm{~km}$, and (ii) in the overriding lower crust, within a partially molten low-

253 viscosity layer, with wavelengths around $30 \mathrm{~km}$ (Figs. 4a and 4b). The thermal instabilities in the 254 low-viscosity crust generate dome-like structures cored by partially molten low-viscosity 
255 material (orange colour in Figs. 4a and 4b). These domes are elongated parallel to the subduction 256 trench and separated by $200-300 \mathrm{~km}$ (Fig. 4a). With time, new thermal domes appear toward 257 the trench, controlled by the flow of low viscosity material in response to both slab rollback and 258 tearing (Fig. 4b; Videos S2-S3 in Appendix 1). The strain rate distribution shows that mature 259 crustal domes preferentially localize deformation, rather than incipient crustal domes closer to 260 the trench (Fig. 4c). In addition, deformation localizes around the edges of these domes, showing 261 the importance of lateral crustal strength contrasts on strain localization (Video S4 in Appendix 262 1). At $14.8 \mathrm{Myr}$, two domes have disappeared but the thickness of the partially molten layer at 263 the base of the crust has tripled (from $\sim 4 \mathrm{~km}$ to $15 \mathrm{~km}$ thick, Fig. 4b; Video S3 in Appendix 1).

264 Meanwhile, the horizontal component of flow velocity in the partially molten layer has decreased 265 (from $\sim 5$ to $\sim 1 \mathrm{~cm} \mathrm{yr}^{-1}$, Fig. 4c). On the opposite, above the slab tear, the deformation is localized 266 (see Fig. 4b in Sternai et al. (2014)) and horizontal component of crustal and mantle velocities 267 have increased up to $\sim 6$ and $\sim 9 \mathrm{~cm} \mathrm{yr}^{-1}$, respectively. The shear heating and the advective mantle 268 heat flow components near the fast velocity zones are enhanced accordingly, as detailed below. 269 


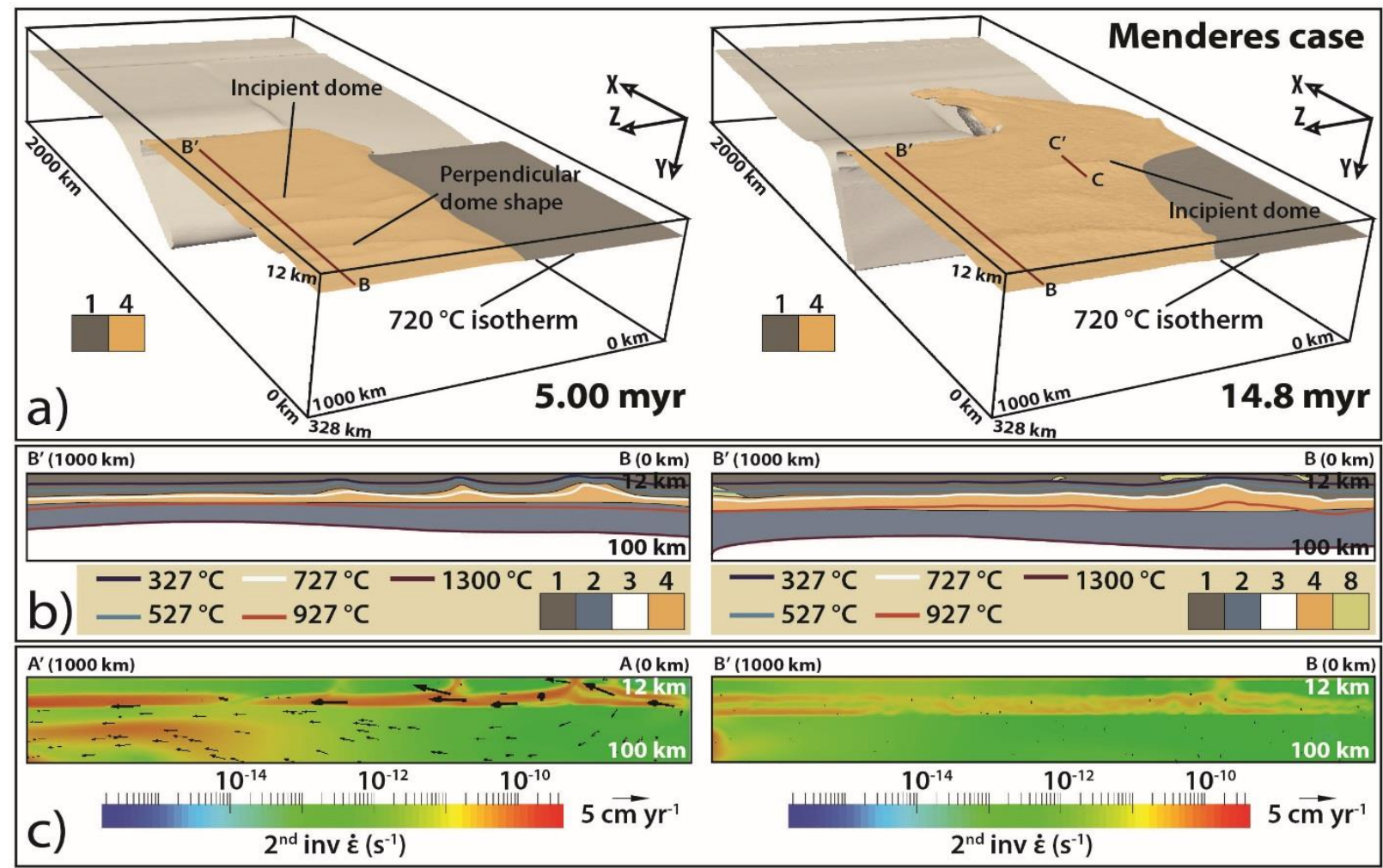

271 Figure 4: Thermo-mechanical evolution of the model. (a) The $720{ }^{\circ} \mathrm{C}$ isotherm at 5 myr and at 27214.8 myr, respectively. Colours showing different rock types: 1, 4 indicate upper and lower crust, 273 respectively, see also Figure 3. Note the position of $\mathrm{CC}^{\prime}$ that may correspond to the 2-D numerical 274 model cross-section. (b) Vertical cross-sections showing different rock types and isotherms. 275 Colours showing different rock types: 1-2-3-4 as defined in Figure 3; 8-hydrated crust. (c) 276 Vertical cross-sections showing the second invariant of the strain rate tensor and velocity vectors.

\subsubsection{Slab dynamics and shear heating}

The contribution of shear heating to heat production in our reference model (with slab

280 tearing between $\mathrm{C} 2$ and the oceanic domain) is compared to similar simulations without slab

281 tearing (Fig. 5; see Fig. S3 in Appendix 1). The frictional heat produced in the overriding plate

282 locally reaches values of $\sim 5.0 \mu \mathrm{W} \mathrm{m}^{-3}$ regardless of slab tearing (Fig. 5). However, when slab

283 tearing occurs, a larger-scale thermal perturbation appears and develops below and at the base of

284 the crust ( $400 \times 200 \mathrm{~km}$ at $12.4 \mathrm{Myr}$; see Fig. 5b). Anomalies associated with shear heating are 
285 thus distributed over a larger domain in the case of tearing because of a more widespread mantle

286 flow around the tear, and appear more localized and parallel to the subduction trench without 287 tearing (Fig. 5a, see right panel). In addition, our results show that the amount of heat produced 288 by shearing leads to an increase of mantle heat flow $\left(Q_{m}\right)$ at the base of the crust, and particularly 289 above the tear. In particular, for average shear heating of $\sim 2.0 \mu \mathrm{W} \mathrm{m}{ }^{-3}$ and mantle thickness of $29030 \mathrm{~km}$ (Fig. 5c, profile 1), the contribution to the heat flow nearby the subduction front is of $\sim 60$ $291 \mathrm{~mW} \mathrm{~m}^{-2}$ at $12.4 \mathrm{Myr}$. Conversely, far from the subduction front, shear heating is insignificant (< $2921.0 \mathrm{nW} \mathrm{m}^{-3}$, see Fig. 5c, profile 4), implying no contribution of this mechanism to heat production 293 by this mechanism (Fig. 5d, profile 1).

294 Shear heating in the mantle during slab retreat and tearing plays a key role in increasing 295 temperatures at the base of the overriding crust, where mantle heat flow values are around 100 $296 \mathrm{~mW} \mathrm{~m}^{-2}$ and reach locally up to $130 \mathrm{~mW} \mathrm{~m}^{-2}$ above the slab tear at $12.4 \mathrm{Myr}$ (Fig. 5b, see left 297 panels). We found that $46 \%$ of the heat flow at the base of the crust is due to mantle shear heating, 298 the remaining part being due to the advection of hot material. In the absence of slab tearing, the 299 average of mantle heat flow at similar times is around $80 \mathrm{~mW} \mathrm{~m} \mathrm{~m}^{-2}$, reaching locally up to 155 $300 \mathrm{~mW} \mathrm{~m}^{-2}$ but over a much smaller area, (Fig. 5b, right). We therefore suggest that advection of hot 301 asthenosphere to shallow depths during slab retreat and tearing plays an important role in 302 increasing temperatures at the base of the crust (Fig. 6). Furthermore, mantle heat flow values 303 may reach steady-state after $\sim 4 \mathrm{Myr}$ (values around $40-50 \mathrm{~mW} \mathrm{~m}{ }^{-2}$, Fig. $5 \mathrm{~d}$ ). 

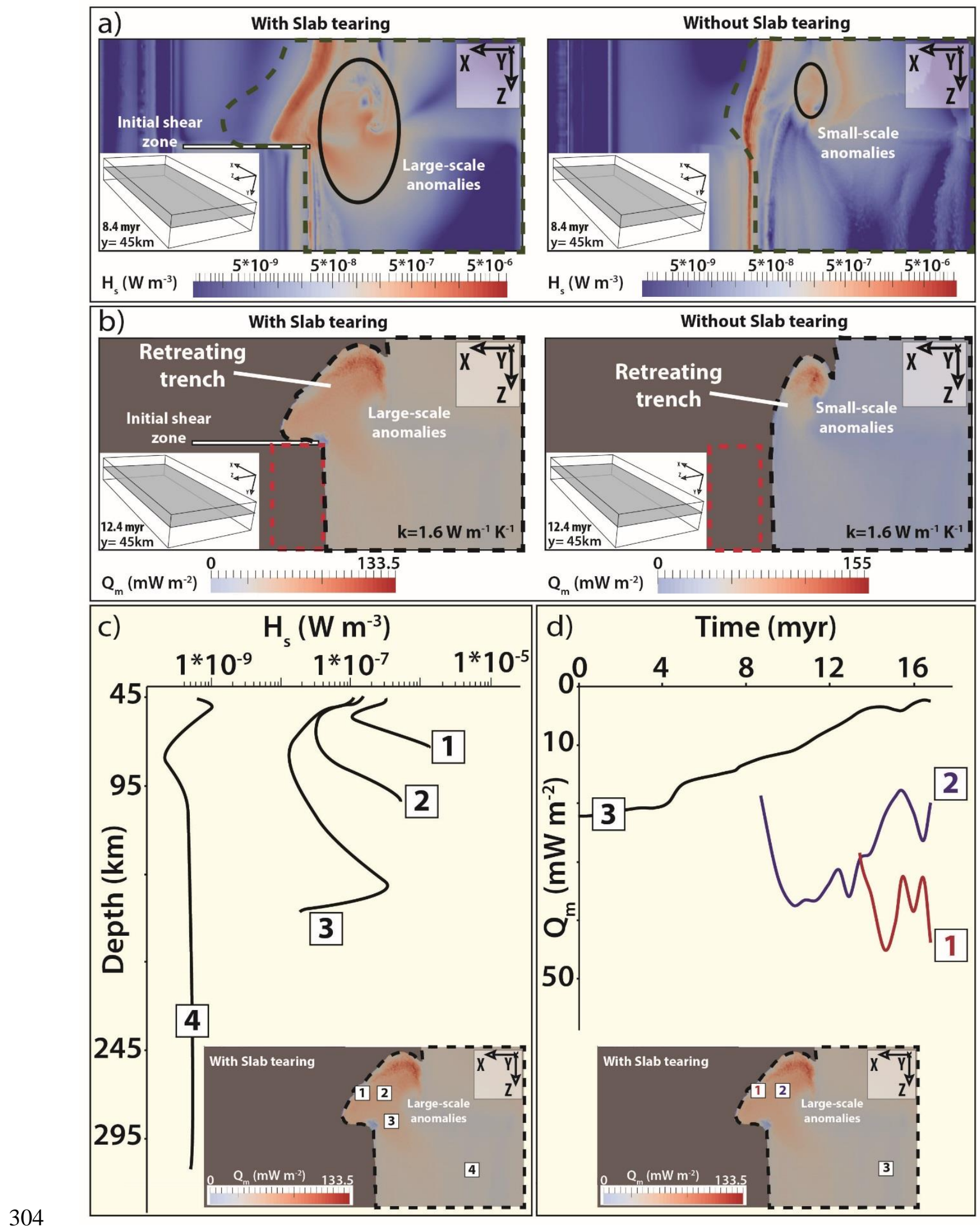

Figure 5: Mantle heat source with and without tearing at the mantle-crust transition. (a) Plan view 
306 of shear heating $\left(\mathrm{H}_{\mathrm{s}}\right)$ at the mantle-crust transition at 8.4 Myr. Dashed line on both panels shows

307 the plan view of the overriding plate C1. (b) Plan view of mantle heat flow $\left(\mathrm{Q}_{\mathrm{m}}\right)$ at the mantle-

308 crust transition at 12.4 Myr. Black and red dashed lines on both panels show the plan view of the

309 overriding mantle, and of the overriding C2, respectively. (c) Vertical depth-shear heating $\left(\mathrm{H}_{\mathrm{s}}\right)$

310 profiles in the mantle below the stretched overriding plate at $t_{0}+14.8$ myr, taken at the location

311 shown by the white squares. (d) Evolution of mantle heat flow $\left(\mathrm{Q}_{\mathrm{m}}\right)$ at the mantle-crust transition.

312 The values are taken at the location shown by the white squares.

To summarize, slab tearing facilitates the rollback of the subducting plate and extension

315 within the upper plate. Consequently, slab tearing and its associated mantle flow contributes to

316 the increase in heat flux at the base of the crust by (i) enhancing mantle shear heating and (ii)

317 controlling the return flow of hot asthenosphere (e.g. toroidal and poloidal mantle flow

318 components). Both mechanisms together appear to be able to increase the Moho temperature by

319 up to $250{ }^{\circ} \mathrm{C}$ (Fig. 6). Therefore, slab tearing may (i) affect the heat source responsible for

320 regional HT-LP metamorphic rocks in MCCs and (ii) explain regional high-temperature

321 anomalies across amagmatic geothermal systems in post-subduction settings.

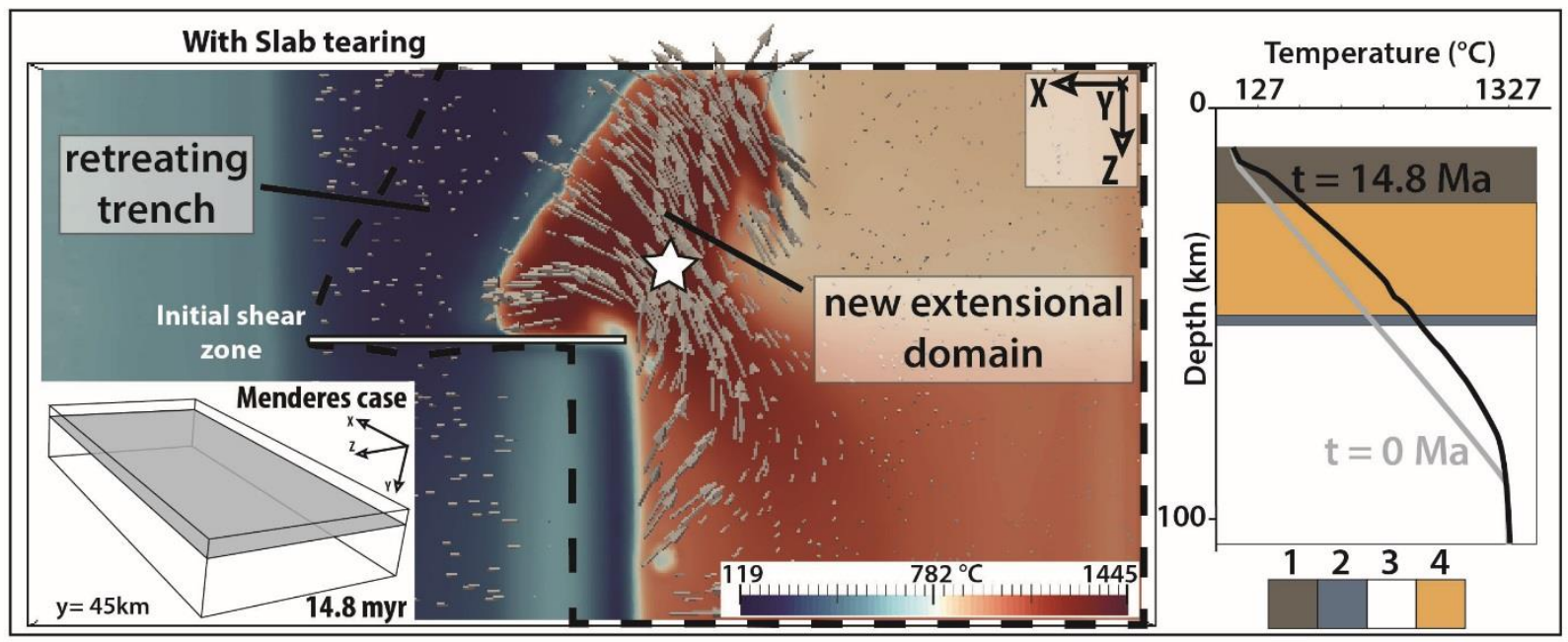


324 Figure 6: Plan view of temperature anomaly at the mantle-crust transition $(\sim 45 \mathrm{~km} \mathrm{depth})$ in the 325 case of slab tearing. Grey arrows represent the velocity vectors in the asthenosphere. Black 326 dashed line on the left panel shows the plan view of the overriding plate C1. Right panel: vertical 327 temperature profiles at $\mathrm{t}_{0}$ and $\mathrm{t}_{0}+14.8 \mathrm{myr}$, taken at the location shown by the white star. Colours 328 showing different rock types: 1-2-3-4, as defined in Figure 3.

\section{FROM SUBCRUSTAL THERMAL ANOMALIES TO GEOTHERMAL SYSTEMS:} 2-D MODEL OF FLUID CIRCULATION high values exceeding $130 \mathrm{~mW} \mathrm{~m}^{-2}$ (Fig. 5b). At $10 \mathrm{~km}$ depth above the tearing, temperature

334 values vary between 450 and $500{ }^{\circ} \mathrm{C}$, and are thus similar to estimated temperatures from 335 aeromagnetic data at the same depth in the Menderes Massif ( $580{ }^{\circ} \mathrm{C}$ ) (Aydin et al., 2005). 336 Using these results, we defined a 2-D fluid flow model in a porous media to analyse the thermal 337 consequences of anomalously high basal heat flow on fluid circulation in the upper crust. The 338 advantage of this model is a good spatial resolution (see Appendix 2), representative 339 permeability, and realistic rock and fluid properties.

340 The model measures $120 \times 10 \mathrm{~km}$ and is designed to represent a SSW-NNE cross section 341 of the Menderes massif. We choose the basal heat flow in order to (1) account for previous 3-D 342 numerical results where mantle heat flow could reach values up to $130 \mathrm{~mW} \mathrm{~m}^{-2}$ (Fig. 5b), and (2) 343 reproduce temperatures above $500{ }^{\circ} \mathrm{C}$ at $10 \mathrm{~km}$ depth, as suggested by Curie-point depths in 344 western Anatolia (Aydin et al., 2005). The objective of this model is to understand the effects of 345 high basal heat flux on the fluid flow circulation pattern, in particular around permeable 346 detachments. In the following, we describe the main characteristics of the model setup and 347 present the main results. 
Coupling between Darcy's law, heat transfer equation and mass conservation is

351 performed using the Comsol Multiphysics ${ }^{\mathrm{TM}}$ software (finite element method). Details about the

352 numerical procedure (benchmark experiments, model setup, fluid and rock properties) are given

353 in Appendix 2. The model is shown in Figure 7, where two detachment faults (with a dip angle

354 varying from 10 to $20^{\circ}$ ) represent the Büyük Menderes and the Alaşehir Menderes detachments

355 (Fig. 2b). Figure 7a illustrates the mesh refinement in permeable zones (close to the surface and

356 within the detachments). A convective flux condition was imposed at the top of the detachments,

357 in order to allow the emergence of hot fluids at the surface. In addition, we use temperature-

358 dependent density and viscosity laws for fluids (see Appendix 2). No magmatic source is present

359 in the model, and the chosen basal heat flow value at a depth of $10 \mathrm{~km}$ corresponds to $120 \mathrm{~mW}$

$360 \mathrm{~m}^{-2}$ (Fig. 7b). This value is therefore consistent with both criteria (i.e. mantle heat flow from our

$3613-\mathrm{D}$ model and Curie-point depths estimations). A constant pressure of $10^{5} \mathrm{~Pa}$ is imposed at the

362 surface allowing fluid influx while no flow is allowed across the others boundaries of the box

363 (Fig. 7b). At time $t=0$, thermal regime is purely conductive (see white isotherms in Fig. 7c).

364 Then, permeability values are switched on (color code of Figure 7c; Appendix 2) and the transient

365 evolution of temperature and velocity fields are recorded during 5 Myr. Permeability in the

366 basement $\left(k_{b}\right)$ decreases exponentially with depth (Manning and Ingebritsen, 1999) (see Fig. 7c

367 and Appendix 2) while detachment permeability is assumed constant $\left(k_{d}\right)$. Despite a number of

368 arguments in such extensional setting suggest high permeability at the surface (highly fractured

369 and karstified rock, see Özen et al. (2012)) numerical values remain unconstrained. We therefore

370 decided to test a wide range of realistic permeabilities for the basement (i.e. from $10^{-17}$ to $10^{-14}$

$371 \mathrm{~m}^{2}$ ) and the detachment fault with same range of values (Fig. 7b). 


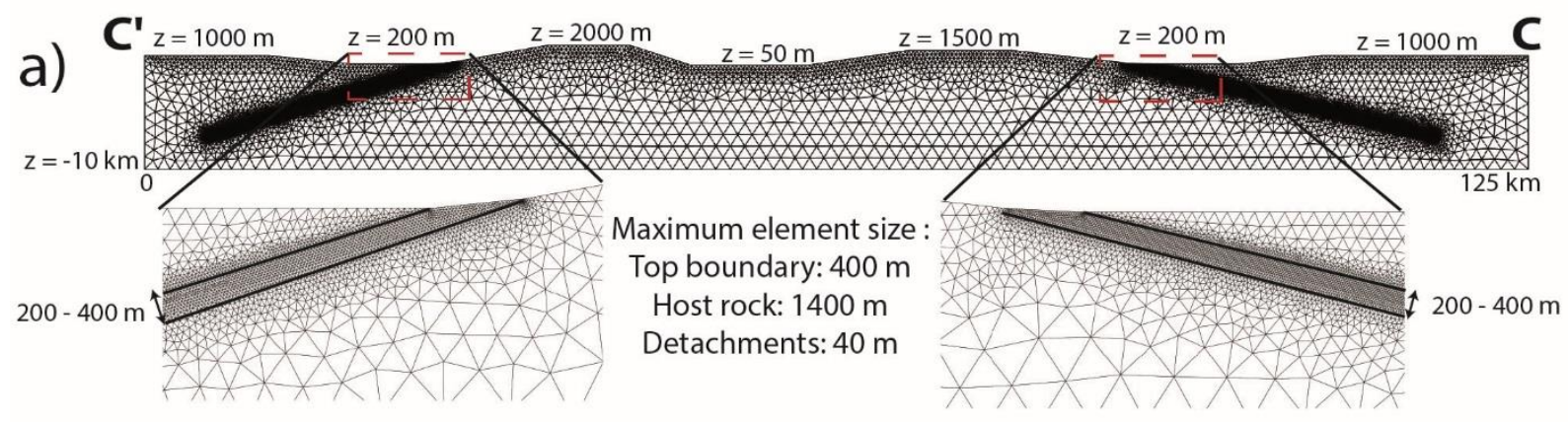

b)

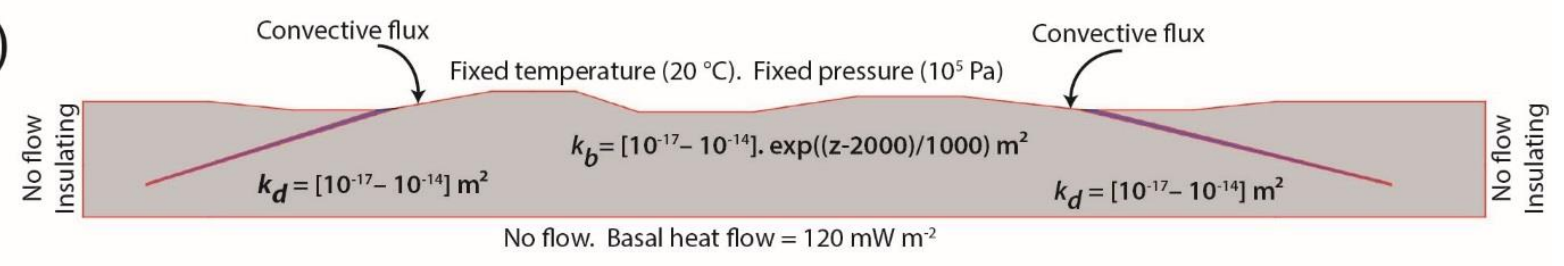

C) Conductive regime $\left(\mathrm{t}_{0}\right)$ : isotherms and permeability field $\left(10^{-14} \exp ((\mathrm{z}-2000) / 1000) \mathrm{m}^{2}\right)$
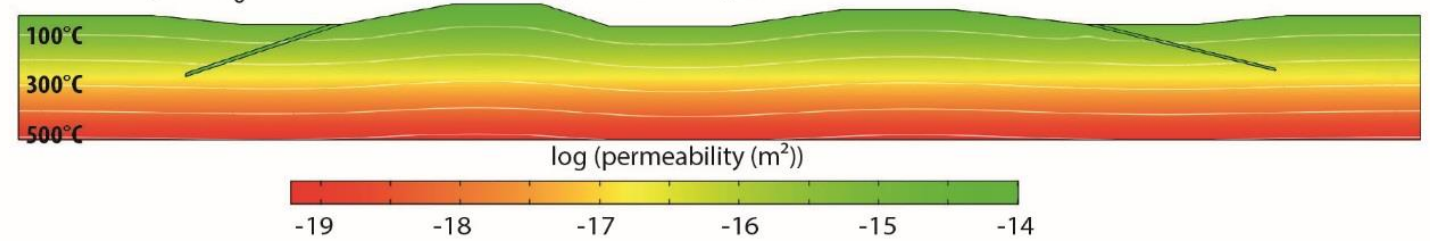

374 Figure 7: (a) Geometry and mesh used for 2-D models of fluid circulation in the upper crust of 375 the Menderes area, where MCCs and detachments are reproduced. This cross section would 376 correspond, from left to right, to a N-S cross section, from Salihli to Salavatli geothermal areas.

377 Mesh is refined at the top surface and within detachments, where permeability is the highest. (b)

378 Boundary conditions and range of values for permeability (note the depth-dependence of the host 379 rock permeability). (c) Steady-state conductive regime, where isotherms in white are separated 380 by $100{ }^{\circ} \mathrm{C}$. Colors refer to permeability values affected at time $\mathrm{t}>0$ (see text) for the case detailed 381 in Figure 9.

\subsection{Results}

\subsubsection{Role of basement and detachment permeabilities}


387 significantly the isotherms, even if $k_{d}$ is high $\left(10^{-14} \mathrm{~m}^{2}\right)$. In the upper case of Figure $8 \mathrm{a}$, isotherms 388 remain flat and no thermal reservoir forms beneath the detachments. Alternatively, the lower case 389 with realistic higher permeability values shows a general fluid circulation pattern characterized 390 by: (i) surface meteoric fluids that flow from topographic highs to the top of the detachment fault 391 and other topographic lows, inducing a negative thermal anomaly in the hanging walls of 392 detachments; (ii) at depth, hot fluids are drained upward by the permeable detachments allowing 393 for isotherms to rise along the fault zones (see uplifted isotherms in bottom case of Fig. 8a). A 394 positive thermal anomaly is due to hot fluids rising up toward the top of the detachment while a 395 negative thermal anomaly induced by topography-driven flow grows in the hanging walls of 396 detachments, leading to the formation of hot fluid reservoirs beneath the detachments (near the 397 surface). To synthetize, at the scale of the whole massif, thermal undulations mimicking dome398 like structures are localized beneath topographic lows in the case of a high basement permeability 399 (Fig. 8a, bottom case). 

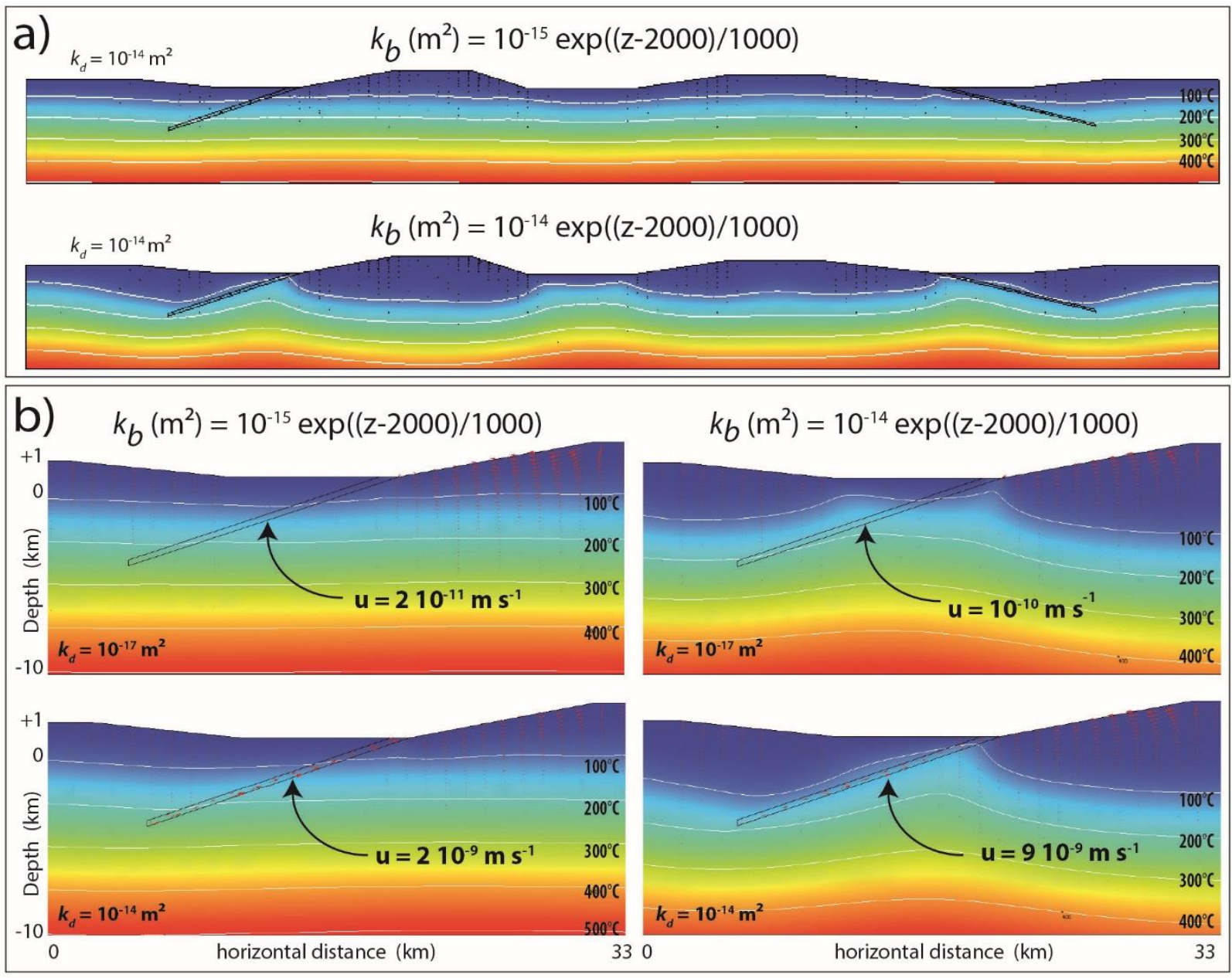

402 Figure 8: Results for thermal perturbations due to fluid circulation in permeable zones for varying 403 basement permeability $\left(k_{b}\right)$ and for varying detachment permeability $\left(k_{d}\right)$. (a) role of the basement 404 permeability for a fixed value of $k_{d}\left(10^{-14} \mathrm{~m}^{2}\right)$. (b) Zoom on the left detachment, with varying 405 permeabilities (small $k_{d}$ value in the top row; high $k_{d}$ value in the bottom row). Left (right) column 406 corresponds to a small (high) basement permeability.

When $k_{d}$ is varied (Fig. 8b), it turns out that thermal reservoirs establish at shallow depth 409 when both $k_{d}$ and maximum $k_{b}$ values are important $\left(10^{-14} \mathrm{~m}^{2}\right.$, bottom right case in Fig. $\left.8 \mathrm{~b}\right)$. In 410 the case where $k_{d}$ is low $\left(10^{-17} \mathrm{~m}^{2}\right.$, top case in Fig. 8b) two thermal reservoirs appear only with a 411 high maximum $k_{b}$ value, suggesting that topography-driven flow is dominant. However, 
412 temperatures at shallow depth and fluid velocity values within the detachment are much lower

413 than in the high $k_{d}$ case (bottom right case in Fig. 8b). Crustal-scale permeable faults and their

414 induced high topography thus control the spatial distribution of upper-crust thermal anomalies at

415 depth, mimicking dome-like structures beneath topographic lows (Fig. 8a, bottom case, and Fig.

4168 b, right column).

\subsubsection{Fluid flow field and temperature profiles}

Figure 9a illustrates the fluid flow velocity pattern in the case of Figure 8a (bottom case).

419 Fluid flow is favored by high-topography and permeable zones such as detachments. Located 420 within detachments, high velocity areas $\left(>10^{-10} \mathrm{~m} / \mathrm{s}-\right.$ or $\left.0.32 \mathrm{~cm} / \mathrm{yr}\right)$ are recorded down to 5

$421 \mathrm{~km}$ deep (red areas). The bottom panel of Figure 9a shows a horizontal temperature profile at 1

$422 \mathrm{~km}$ depth. It is important to note that temperature anomalies of $\sim 140{ }^{\circ} \mathrm{C}$ are focused close to the

423 top of the detachments. Figure $9 \mathrm{~b}$ (left column) shows computed vertical temperature profiles at

424 different distances from the two detachments, at a given time (i.e. 4 x $10^{4} \mathrm{yr}$ ). Figure $9 \mathrm{~b}$ (right

425 column) illustrates temperature measurements at the Aydin-Salavatlı geothermal field, Büyük

426 Menderes Graben, within 2 boreholes $\sim 1.5 \mathrm{~km}$ apart. Although the comparison of daily-measured

427 thermal profiles with these two sets of vertical temperature profiles is limited, one can observe

428 some similarities with (i) a high-temperature gradient at the surface, decreasing rapidly with

429 depth, and (ii) some negative values of the temperature gradient. In addition, modeled

430 temperatures are comparable, with emergence temperatures around $60{ }^{\circ} \mathrm{C}$ and reservoir

431 temperatures at depth around $180-200{ }^{\circ} \mathrm{C}$. Because our density law is simplified (see Appendix

432 2), and because the vapour phase is not accounted for, the computed profiles show rather smooth

433 curves when compared to measurements. However, the typical convective signatures in 434 temperature profiles are similar. 

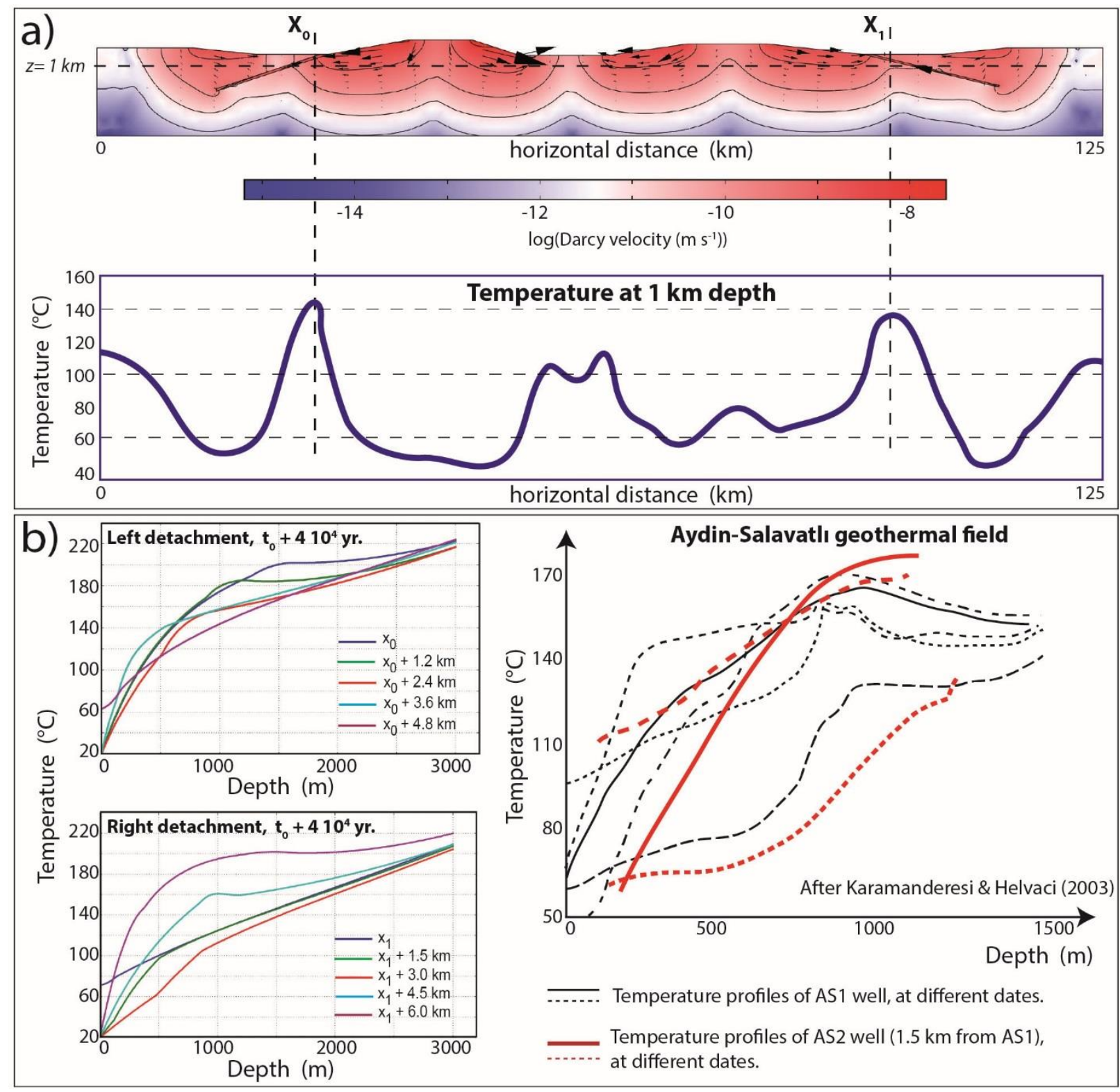

437 Figure 9: Results for the experiment shown in the lower case of Figure 8a (and right case of 438 Figure 8b). (a) Fluid flow velocity field (colors, isocontours and arrows) and horizontal 439 temperature profile at $1 \mathrm{~km}$ depth (dashed line in the fluid flow pattern). Note that the largest 440 temperature perturbations correspond to the top of the detachment locations ( $\mathrm{x}_{0}$ and $\left.\mathrm{x}_{1}\right)$. (b) 441 Computed vertical temperature profiles at time to $+410^{4} \mathrm{yr} . \mathrm{x} 0$ and $\mathrm{x} 1$ are indicated in Figure 9a. 442 On the right, measured temperature profiles at the Aydin-Salavatli geothermal field; black curves 
443 (plain and dashed) correspond to different measures in the same AS1 borehole (different dates of 444 measurements) and red lines are measured in the AS2 borehole, $1.5 \mathrm{~km}$ from the AS1 borehole 445 (after Karamanderesi and Helvaci, 2003).

\section{DISCUSSION}

\section{Anatolia}

The modeled thermo-mechanical instabilities (Fig. 4) are not only analogous to crustal

451 and lithospheric boudinage (Ricard and Froidevaux, 1986), but they add a thermal component to

452 what was generally assumed to be purely mechanical. These instabilities developed in the

453 overriding plate are triggered by both shear heating and hot mantle flows. These mechanisms

454 indeed induce a thermal weakening of the lithosphere, thus controlling the development of 455 boudinage at different scales, and the localization of MCCs in the extensional crust. It is important 456 to note that these domes are also promoted by the low-viscosity crust, which is related to the 457 chosen initial thermal regime in our models. When the slab tear is accounted for, the crust is weak 458 over a wider domain above the tear, increasing its ability to flow (e.g. Block and Royden, 1990;

459 Rey et al., 2009) and to form HT domes. In other words, shear heating and mantle flow control 460 the position of positive thermal anomalies in the overriding crust, which, in turn, control the 461 deformation pattern in the lower crust during extension. Such a lithospheric thermal weakening 462 is further enhanced by the accumulation of magmas in the back-arc domain, which is widely 463 promoted by slab rollback and tearing processes (Menant et al., 2016b).

464 In the Cyclades (Greece), the dominant wavelength of MCCs (several tens of kilometres, 465 similar to the spacing between the different islands) is compatible with that expected for crustal466 scale boudinage (Fig. 4). At the scale of the whole Aegean domain, long-wavelength variations 
467 of Moho depth (Tirel et al., 2004; Karabulut et al., 2013) are more reminiscent of lithospheric-

468 scale boudinage (several hundreds of km; Fig. 4). This boudinage of the crust induces migmatite-

469 cored MCCs which were first exhumed in the northern Menderes Massif in the Micoene (Cenki-

470 Tok et al., 2016), and then in the central and eastern Cyclades since the lower Miocene (Jolivet

471 et al., 2015), coevally with a further acceleration of trench retreat related to the Hellenic slab

472 tearing. This is consistent with our model, where dome-like structures, cored by partially molten

473 low-viscosity material, develop first in the overriding plate, and then migrate toward the trench,

474 in response to both slab rollback and tearing (Figs. $4 \mathrm{a}$ and $4 \mathrm{~b}$ ). In addition, we suggest also that

475 excess heat due to these subduction dynamics controlled the retrogression in the greenschist-

476 facies of high-pressure metamorphic rocks in Cyclades (post-orogenic extension), consistently

477 with acceleration of slab retreat around $35 \mathrm{Ma}$ (Jolivet et al., 2015). Furthermore, our numerical

478 experiments highlight an increase of Moho temperature during a few Myrs related to

479 asthenosphere upwelling below the overriding plate (Figs. 5d and 6). We therefore suggest a

480 similar heating for the mantle-crust boundary in the Anatolian-Aegean domain, which is

481 consistent with the presence of HT metamorphic domes and the formation of syn-extension

482 granites and migmatites throughout the entire western Anatolian-Aegean domain between $20 \mathrm{Ma}$

483 and $8 \mathrm{Ma}$ (Jolivet et al., 2015; Menant et al., 2016a).

484 In the Menderes MCC (located above the slab tear, see Fig. 2), strain was first localized 485 in the north, along the Simav Detachment (early Miocene, stage 1 after Gessner et al. 2013) 486 accommodating the exhumation of an asymmetric migmatite-cored MCC (Rey et al., 2009;

487 Cenki-Tok et al., 2016). Then, strain migrated southward, toward the trench and localized within 488 the central part of the Menderes Massif (Fig. 2c). The Alaşehir and Büyük Menderes detachments 489 assisted exhumation of the lower crust during slab tearing (middle-late Miocene, stage 2 after 
491 than the previously activated Simav area, probably due to the extra source of heat associated with

492 slab tearing. According to Labrousse et al. (2016), the evolution of the style of extension from an

493 asymmetric MCC (localized deformation, case of the Simav detachment) to a double-dome

494 symmetric MCC (distributed deformation, case of the Menderes detachments) implies that heat

495 input at the base of the crust is higher than heat dissipation due to stretching. These observations

496 are consistent with the thermal features observed in our model, which emphasize the crucial role

497 of shear heating, as well as poloidal and toroidal components of mantle flow, to heat the lower

498 crust (Figs. 5 and 6). Both mechanisms are thus responsible for the presence of large-scale

499 thermal anomalies at depth (i.e. $580{ }^{\circ} \mathrm{C}$ at $10 \mathrm{~km}$ depth) and at the surface (i.e. heat flow values

500 around $100 \mathrm{~mW} \mathrm{~m}^{-2}$, Erkan, 2015). As a consequence, the thermal state of the crust induced by

501 elevated mantle heat flow could control the style of extension (asymmetric versus symmetric 502 MCC).

503 Furthermore, hot fluids circulating within crustal-scale permeable faults help increasing 504 basal temperatures (around the ductile/brittle transitions) by several tens of ${ }^{\circ} \mathrm{C}$ (Fig. 8a), resulting 505 in a positive feedback for the formation of new shear zones and MCCs at depth. In this case, 506 magmatic bodies such as granitoids and migmatites may be developed and localized below the 507 detachment, as it seems to be the case in the Menderes with the Salihli diorite and Simav granites. 508 The progressive formation of HT domes topped with extensional detachments can thus 509 be summarized as follows: (1) mechanical (boudinage) and thermal instabilities within the 510 stretched lithosphere generate a series of domes, periodically spaced, producing rheological 511 heterogeneities (i.e. low-viscosity layers) that are likely to localize extensional shearing 512 deformation on their edges (Le Pourhiet et al., 2003; Huet et al., 2011) and (2) upward flow of 
513 deep hot fluids and downward flow of cold surface fluids further increase thermal contrasts across

514 the shear zones, enhancing the localization of deformation.

518 are similar to that documented in MCCs, and may be associated with crustal-scale permeable

519 faults, which can provide pathways for meteoric waters to flow into the actively deforming 520 middle crust (e.g. Famin et al., 2005; Mulch et al., 2006). As shown in Figure 5, the excess of

521 mantle heat flow is transfered by conduction into the crust, affecting the fluids present in the

522 crustal porosity. These fluids may then undergo deformation-driven flow in ductile shear zones

523 (e.g. Oliver, 1996), but also thermally driven (i.e. buoyancy-driven) flow through the crust, where

524 high permeability detachments may easily collect and bring up deep hot fluids. Indeed, our 2-D

525 numerical models suggest that an elevated basal temperature $\left(580{ }^{\circ} \mathrm{C}\right)$ at $10 \mathrm{~km}$ depth would

526 induce temperatures of $300-350{ }^{\circ} \mathrm{C}$ at a depth of $6 \mathrm{~km}$ and thus a sufficiently high fluid density

527 contrast to permit upward flow along the low-angle fault in the shallower crust. In that case,

528 buoyancy-driven flow is superimposed to topography-driven flow (Fig. 8). In other words, the

529 topography-driven flow, which prevails in the regional fluid flow pattern, is dominated by

530 buoyancy-driven flow within highly permeable detachments.

531 Although the spatiotemporal evolution of permeability within detachments is poorly

532 known, field observations on these geological structures (Famin et al., 2005) suggest that they

533 could represent highly permeable zones of several hundreds of meters thick where fluid flow is

534 facilitated (Fig. 10). Moreover, if these channelized fluid flow systems are tectonically active,

535 earthquake faulting may be associated with seismic pumping that enhances fluid migration 
toward dilation zones (Sibson et al., 1975; Famin et al., 2005). As a consequence, detachments

537 may be considered as the crustal-scale structural control for the circulation of deep geothermal

538 fluids related to HEGRs (e.g. Bellani et al., 2004; Roche et al. submitted), driving the long-term

539 crustal-scale history of the geothermal systems (Fig. 10). However, it is noteworthy that most of

540 the geothermal systems in the Menderes Massif reside in fault intersection zones, where N-S

541 transfer faults and low-angle normal faults mostly formed dilational jogs that seem to promote

542 the emergence of hot waters and gas vents (Roche et al., submitted). Fault interactions would

543 thus allow for fluid rising in the hanging wall from the reservoirs located below the detachment

544 (Fig. 8b, right column), and control the location of thermal springs. Further numerical simulations

545 would therefore be required to confirm this hypothesis based on field observations.

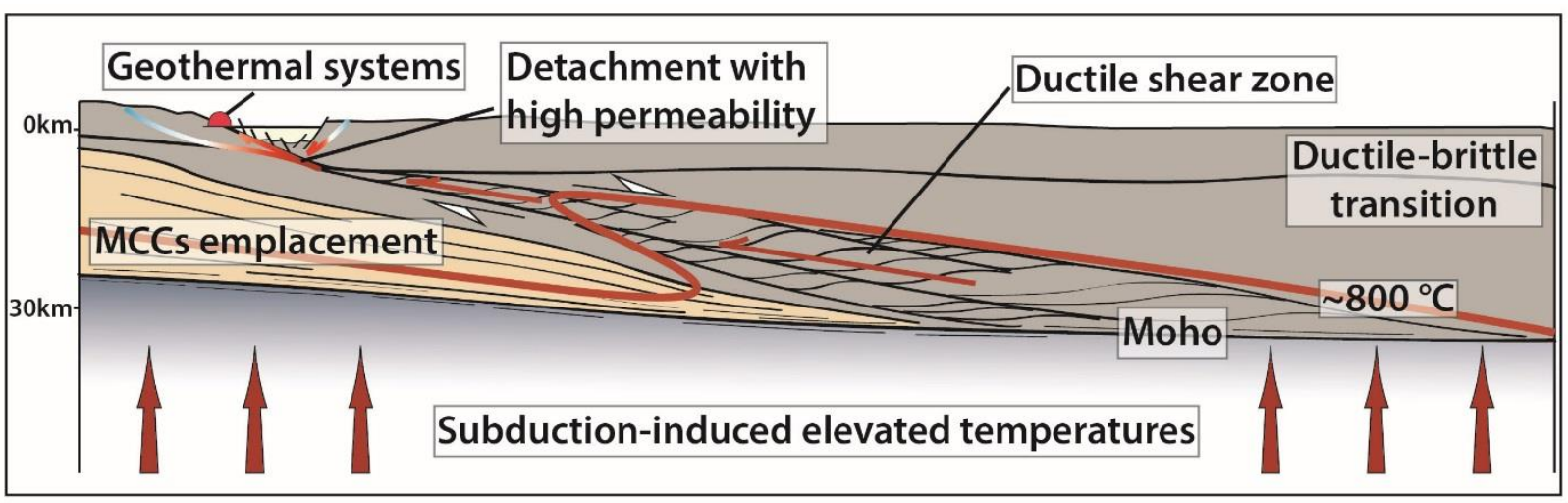

548 Figure 10: Schematic cross section showing fluid flow associated with detachment zone in back-

549 arc area. Red arrows indicate fluid circulation in ductile crust and circulation of meteoric fluids

550 in the upper crust are underlined by colored pathways (blue for cold and red for warm). 


\section{Basin and Range (Western United States) areas}

Our 3-D and 2-D model results are relevant to other regions, and thus may explain

555 relationships between subduction dynamics and the location of geothermal provinces; for

556 instance, (i) in the Larderello area post-orogenic extension is active in back-arc domain; or (ii) in

557 the Basin and Range Province (western United States). In both cases, MCCs are exhumed along

558 low-angle normal faults, and therefore represent a favorable setting for HEGRs. While some of

559 them are considered as "amagmatic" in origin (e.g. Bellani et al., 2004; Faulds et al., 2010), some

560 authors require a magmatic heat source (e.g. Koenig and McNitt, 1983; Santilano et al. 2015).

561 Through these two main additional examples, we show that the "magmatic" vs. "amagmatic"

562 classification may be ambiguous according to the long-term behavior of these geothermal 563 systems.

564 In the Northern Tyrrhenian Sea and Tuscany regions, subduction dynamics has also been 565 controlled by slab retreat since the Oligo-Miocene. This region is characterized by a shallow 566 Moho discontinuity (20 $-25 \mathrm{~km}$ depth), and a reduced lithosphere thickness due to uprising 567 asthenosphere and the delamination of crustal lithosphere (Gianelli, 2008). At crustal-scale a 568 series of low-angle normal faults crosscut the old thrusts (e.g. Faccenna et al., 1997; Jolivet et $569 a l ., 1998)$, and thus cannot be explained by a reactivation of pre-existing inherited discontinuities.

570 Instead, our numerical models suggest that thermo-mechanical boudinage induced by slab 571 rollback triggers the formation of localized shear zones and allows the exhumation of MCCs (e.g.

572 Elba Islands, Fig. S4 in Appendix 1). These shear zones are still active (Bellani et al., 2004) and 573 may control the ascent of magmatic intrusions, such as beneath the Larderello geothermal field. 
574 We therefore suggest that magmatic intrusions in the upper crust result directly from the deep

575 thermal anomaly associated with slab dynamics during extension.

576 Although subduction dynamics are quite different in the Basin and Range province (i.e.

577 first characterized by slab retreat since the Eocene at the northern edge of the Farallon slab

578 (Schellart et al., 2010), and then by an asthenospheric upwelling above the Californian slab

579 window at $30 \mathrm{Ma}$ (Atwater, 1970)), similar remarks also hold for this region. Indeed, our results

580 are consistent with geological observations where the presence of a conductor at $15-35 \mathrm{~km}$

581 depth range (Wannamaker et al., 2008) suggests that the central part of the Basin and Range

582 domain has become weaker, probably due to an extra source of heat associated with slab window

583 (i.e. magma underplating due to mantle flow and shear heating). In light of our numerical results,

584 we propose that fast-flowing asthenosphere also strongly heats the lithospheric mantle and the

585 lower crust via shear heating and mantle upwelling processes. Lithospheric weakening thus

586 promotes the propagation of major fault zones throughout the crust, leading to the connection

587 between the weaker conductive lower crust and the brittle upper crust (Fig. 10). Hot thermal

588 fluids at depth can then ascend within the damage fault zones, which thus control the location of

589 HEGRs at the surface (Faulds et al., 2010). It is noteworthy that the presence of recent intrusions

590 (e.g. Steam Boat, Casa Diablo in the Walker Lane geothermal belt, Koenig and McNitt, 1983)

591 locally enhances thermally-driven flow, by increasing the temperatures of the geothermal systems

592 but this seems marginal as little active volcanism is recognized in this region (Faulds et al., 593 2010). 
3-D numerical experiments show that the mantle flow and shear heating resulting from

597 slab retreat and tearing have a significant effect on Moho temperatures during 5-10 Myrs. Such

598 a mechanism induces lithospheric and crustal thermal boudinage with different wavelengths,

599 which in turn creates thermally-driven rheological contrasts that localize deformation and lead to

600 the formation of crustal-scale permeable detachments. These structures allow for the exhumation

601 of MCCs and for the emplacement of HEGRs comparable to those observed in the Mediterranean

602 realm and in the Western United States. Although there is no consensus on a worldwide

603 classification of geothermal systems, our results highlight the importance of the spatial and

604 temporal scales of subduction dynamics in the control of genesis of geothermal systems.

605

606 ACKNOWLEDGMENTS

607 This work has been financially supported by the LABEX VOLTAIRE (ANR-10-LABX-

608 100-01) of the University of Orléans and by the French Geological Survey (BRGM). This paper

609 is a contribution of the ERC RHEOLITH Project (ERC advanced grant no. 290864). Pietro

610 Sternai is grateful to the Swiss NSF Ambizione grant PZ00P2_168113/1. Numerical simulations

611 were performed on the ETH-Zürich clusters BRUTUS and EULER. The paper benefited from 612 relevant revisions by David Whipp and one anonymous reviewer.

613 


\section{REFERENCES}

615 Aydın, İ., Karat, H. İ., and A., Koçak. (2005), Curie-point depth map of Turkey. Geophysical 616 Journal International, 162(2), 633-640.

617 Bertani, R. (2016), Geothermal power generation in the world 2010-2014 update report. 618 Geothermics, 60, 31-43.

619 Bellani, S., Brogi, A., Lazzarotto, A., Liotta, D., and G., Ranalli. (2004), Heat flow, deep 620 temperatures and extensional structures in the Larderello Geothermal Field (Italy): 621 constraints on geothermal fluid flow: Journal of Volcanology and Geothermal Research, $622 \quad 132(1), 15-29$.

623 Blackwell, D. D., Smith, R. P., Waibel, A., Richards, M. C., and P., Step. (2009). Why Basin

624 and Range systems are hard to find II: Structural model of the producing geothermal 625 system in Dixie Valley, Nevada. Geothermal Resources Council Transactions, 33, 441-446. 626 Block, L., and L.H., Royden. (1990), Core complex geometries and regional scale flow in the 627 lower crust: Tectonics 9, 557-567.

628 Bousquet, R., Goffe, B., Henry, P., LePichon, X., and C., Chopin. (1997), Kinematic, thermal 629 and petrological model of the Central Alps: lepontine metamorphism in the upper crust and 630 eclogitisation of the lower crust: Tectonophysics 273, 105-127.

631 Bozkurt, E., Satır, M., and Ç., Buğdaycığlu. (2011), Surprisingly young Rb/Sr ages from the 632 Simav extensional detachment fault zone, northern Menderes Massif, Turkey. Journal of 633 geodynamics, 52(5), 406-431.

634 Brogi, A., Capezzuoli, E., Martini, I., Picozzi, M., and F., Sandrelli. (2014), Late Quaternary 635 tectonics in the inner Northern Apennines (Siena Basin, southern Tuscany, Italy) and their 636 seismotectonic implication. Journal of Geodynamics: 76, 25-45. 
637 Cenki-Tok, B., Expert, M., Işık, V., Candan, O., Monié, P., and O., Bruguier. (2016), Complete 638 Alpine reworking of the northern Menderes Massif, western Turkey: International Journal 639 of Earth Sciences, 105(5), 1507-1524.

640 Cumming, W. (2009), Geothermal resource conceptual models using surface exploration data. 641 In Proceedings.

642 De Boorder, H., Spakman, W., White, S. H., and M. J. R., Wortel. (1998), Late Cenozoic 643 mineralization, orogenic collapse and slab detachment in the European Alpine Belt. Earth 644 and Planetary Science Letters, 164(3), 569-575.

645 Erkan, K. (2015), Geothermal investigations in western Anatolia using equilibrium 646 temperatures from shallow boreholes. Solid Earth, 6(1), 103.

647 Faccenna, C., Mattei, M., Funiciello, R. and L., Jolivet. (1997), Styles of back-arc extension in 648 the Central Mediterranean: Terra Nova, 9, 126-130.

649 Famin, V., Philippot, P., Jolivet, L., and P., Agard. (2004), Evolution of hydrothermal regime 650 along a crustal shear zone, Tinos Island, Greece. Tectonics, 23(5).

651 Faulds, J., Coolbaugh, M., Bouchot, V., Moek, I., \& Oguz, K. (2010). Characterizing structural 652 controls of geothermal reservoirs in the Great Basin, USA, and Western Turkey:

653 Developing successful exploration strategies in extended terranes. In World Geothermal 654 Congress 2010 (pp. 11-p).

655 Gerya, T. (2010), Introduction to Numerical Geodynamic Modelling: Cambridge University 656 Press.

657 Gessner, K., Gallardo, L. A., Markwitz, V., Ring, U., and S. N., Thomson. (2013), What caused 658 the denudation of the Menderes Massif: Review of crustal evolution, lithosphere structure, 659 and dynamic topography in southwest Turkey: Gondwana Research, 24(1), 243-274. 
660 Gessner, K., Markwitz, V., and T., Güngör, (2017), Crustal fluid flow in hot continental

661 extension: tectonic framework of geothermal areas and mineral deposits in western

662 Anatolia. Geological Society, London, Special Publications, 453, SP453-7.

663 Gianelli, G. (2008). A comparative analysis of the geothermal fields of Larderello and Mt.

664 Amiata, Italy. Geothermal energy research trends. Nova Science, New York, 59-85.

665 Hetzel, R., Passchier, C. W., Ring, U. and O. O., Dora. (1995), Bivergent extension in orogenic

666 belts: the Menderes massif (southwestern Turkey): Geology, 23, 455-458.

667 Huet, B., Le Pourhiet, L., Labrousse, L., Burov, E., and L., Jolivet. (2011), Post-orogenic

668 extension and metamorphic core complexes in a heterogeneous crust: the role of crustal

669 layering inherited from collision. Application to the Cyclades (Aegean domain).

670 Geophysical Journal International, 184(2), 611-625.

671 Jolivet, L., Faccenna, C., Goffé, B., Mattei, M., Rossetti, F., Brunet, C., ... and T., Parra. (1998),

672 Midcrustal shear zones in postorogenic extension: example from the northern Tyrrhenian

673 Sea: Journal of Geophysical Research: Solid Earth, 103(B6), 12123-12160.

674 Jolivet, L., Famin, V., Mehl, C., Parra, T., Aubourg, C., Hébert, R., and P., Philippot. (2004),

675 Strain localization during crustal-scale boudinage to form extensional metamorphic domes

676 in the Aegean Sea: Geological Society of America Special Papers, 380, 185-210.

677 Jolivet, L., and J. P., Brun. (2010), Cenozoic geodynamic evolution of the Aegean. International $678 \quad$ Journal of Earth Sciences, 99(1), 109-138.

679 Jolivet, L., Menant, A., Sternai, P., Rabillard, A., Arbaret, L., Augier, R., ... and L., Labrousse.

680 (2015), The geological signature of a slab tear below the Aegean: Tectonophysics, 659,

$681 \quad 166-182$.


682 Karabulut, H., Paul, A., Ergün, T. A., Hatzfeld, D., Childs, D. M., and M., Aktar. (2013), Long-

683 wavelength undulations of the seismic Moho beneath the strongly stretched Western

684 Anatolia: Geophysical Journal International, 194(1), 450-464.

685 Karamanderesi, İ. H., and C., Helvaci. (2003), Geology and hydrothermal alteration of the 686 Aydın-Salavatlı geothermal field, western Anatolia, Turkey. Turkish Journal of Earth 687 Sciences, 12(2), 175-198.

688 Kaya, A. (2015), The effects of extensional structures on the heat transport mechanism: An 689 example from the Ortakçı geothermal field (Büyük Menderes Graben, SW Turkey). Journal 690 of African Earth Sciences, 108, 74-88.

691 Koenig, J. B., and J.R., McNitt. (1983), Controls on the location and intensity of magmatic and

692 non-magmatic geothermal systems in the Basin and Range province: Geothermal 693 Resources Council (No. 13, p. 93). Special Report.

694 Labrousse, L., Huet, B., Le Pourhiet, L., Jolivet, L., and E., Burov. (2016), Rheological

695 implications of extensional detachments: Mediterranean and numerical insights: Earth696 Science Reviews, 161, 233-258.

697 Le Pourhiet, L., Burov, E., and I., Moretti. (2003), Initial crustal thickness geometry controls on 698 the extension in a back arc domain: Case of the Gulf of Corinth. Tectonics, 22(4).

699 Manning, C. E., \& Ingebritsen, S. E. (1999). Permeability of the continental crust: Implications 700 of geothermal data and metamorphic systems. Reviews of Geophysics, 37(1), 127-150.

701 Menant, A., L. Jolivet, and B., Vrielynck. (2016a), Kinematic reconstructions and magmatic 702 evolution illuminating crustal and mantle dynamics of the eastern Mediterranean region 703 since the late Cretaceous: Tectonophysics, 675, 103-140;

$704 \quad$ doi:110.1016/j.tecto.2016.1003.1007. 
705 Menant, A., Sternai, P., Jolivet, L., Guillou-Frottier, L., and T., Gerya. (2016b), 3D numerical

706 modeling of mantle flow, crustal dynamics and magma genesis associated with slab roll-

707 back and tearing: The eastern Mediterranean case. Earth and Planetary Science Letters,

$708 \quad 442,93-107$.

709 Mezri, L., Le Pourhiet, L., Wolf, S., and E., Burov (2015), New parametric implementation of

710 metamorphic reactions limited by water content, impact on exhumation along detachment

711 faults, Lithos, 236-237, 287-298; http://dx.doi.org/210.1016/j.lithos.2015.1008.1021.

712 Moeck, I. S. (2014), Catalog of geothermal play types based on geologic controls. Renewable

713 and Sustainable Energy Reviews, 37, 867-882.

714 Mulch, A., Teyssier, C., Cosca, M. A., and T. W., Vennemann. (2006), Thermomechanical

715 analysis of strain localization in a ductile detachment zone: Journal of Geophysical

716 Research: Solid Earth, 111(B12).

717 Oliver, N. H. S. (1996), Review and classification of structural controls on fluid flow during

718 regional metamorphism: Journal of Metamorphic Geology, 14(4), 477-492.

719 Özen, T., Bülbül, A., and G., Tarcan. (2012), Reservoir and hydrogeochemical

720 characterizations of geothermal fields in Salihli, Turkey. Journal of Asian Earth Sciences,

$721 \quad 60,1-17$

722 Ozdemir, A., Yasar, E., and G., Cevik. (2017), An importance of the geological investigations

723 in Kavaklıdere geothermal field (Turkey). Geomechanics and Geophysics for Geo-Energy

724 and Geo-Resources, 3(1), 29-49.

725 Piromallo, C., and A., Morelli. (2003), P wave tomography of the mantle under the Alpine-

726 Mediterranean area. Journal of Geophysical Research: Solid Earth, 108(B2). 
727 Rey, P.F., Teyssier, C., and D.L., Whitney. (2009), The Role of Partial Melting and Extensional 728 Strain Rates in the Development of Metamorphic Core Complexes, in Chardon, D., Rey, 729 P., Teyssier, C., and Whitney, D.L., eds., Hot Orogen: Tectonophysics, v. 477, p. 135-144.

730 Reynolds, S. J., and G. S., Lister. (1987), Structural aspects of fluid-rock interactions in 731 detachment zones: Geology, 15(4), 362-366.

732 Roche, V., Bouchot, V., Beccaletto, L., Jolivet, L., Guillou-Frottier, L., Tuduri, J., Bozkurt, E., 733 Oguz, K., and B., Tokay. (submitted), Structural, lithological and geodynamic controls on 734 geothermal activity in the Menderes geothermal Province (Western Anatolia, Turkey): $735 \quad$ IJES.

736 Ricard, Y., and C., Froidevaux. (1986), Stretching instabilities and lithospheric boudinage: 737 Journal of Geophysical Research: Solid Earth, 91(B8), 8314-8324.

738 Santilano, A., Manzella, A., Gianelli, G., Donato, A., Gola, G., Nardini, I., ... and S., Botteghi. 739 (2015), Convective, intrusive geothermal plays: what about tectonics?. Geothermal Energy $740 \quad$ Science, 3(1), 51-59.

741 Schellart, W. P., Stegman, D. R., Farrington, R. J., Freeman, J., and L., Moresi. (2010),

742 Cenozoic tectonics of western North America controlled by evolving width of Farallon $743 \quad$ slab. Science, 329(5989), 316-319.

744 Schubert, G., and Yuen, D. A. (1978), Shear heating instability in the Earth's upper mantle. 745 Tectonophysics, 50(2-3), 197-205.

746 Sibson, R. H., Moore, J. M. M., and A. H., Rankin. (1975), Seismic pumping — a hydrothermal 747 fluid transport mechanism: Journal of the Geological Society, 131(6), 653-659. 
748 Sternai, P., L. Jolivet, A. Menant, and T., Gerya. (2014), Driving the upper plate surface

749 deformation by slab rollback and mantle flow: Earth Planet. Sci. Lett., 405, 110-118,

$750 \quad$ doi:10.1016/j.epsl.2014.08.023.

751 Tirel, C., Gueydan, F., Tiberi, C., and J.P., Brun. (2004), Aegean crustal thickness inferred from

752 gravity inversion. Geodynamical implications. Earth and Planetary Science Letters, 228(3),

$753 \quad 267-280$.

754 Wannamaker, P. E., Hasterok, D. P., Johnston, J. M., Stodt, J. A., Hall, D. B., Sodergren, T. L.,

$755 \quad$... and M. J., Unsworth. (2008), Lithospheric dismemberment and magmatic processes of

756 the Great Basin-Colorado Plateau transition, Utah, implied from magnetotellurics.

757 Geochemistry, Geophysics, Geosystems, 9(5).

758 


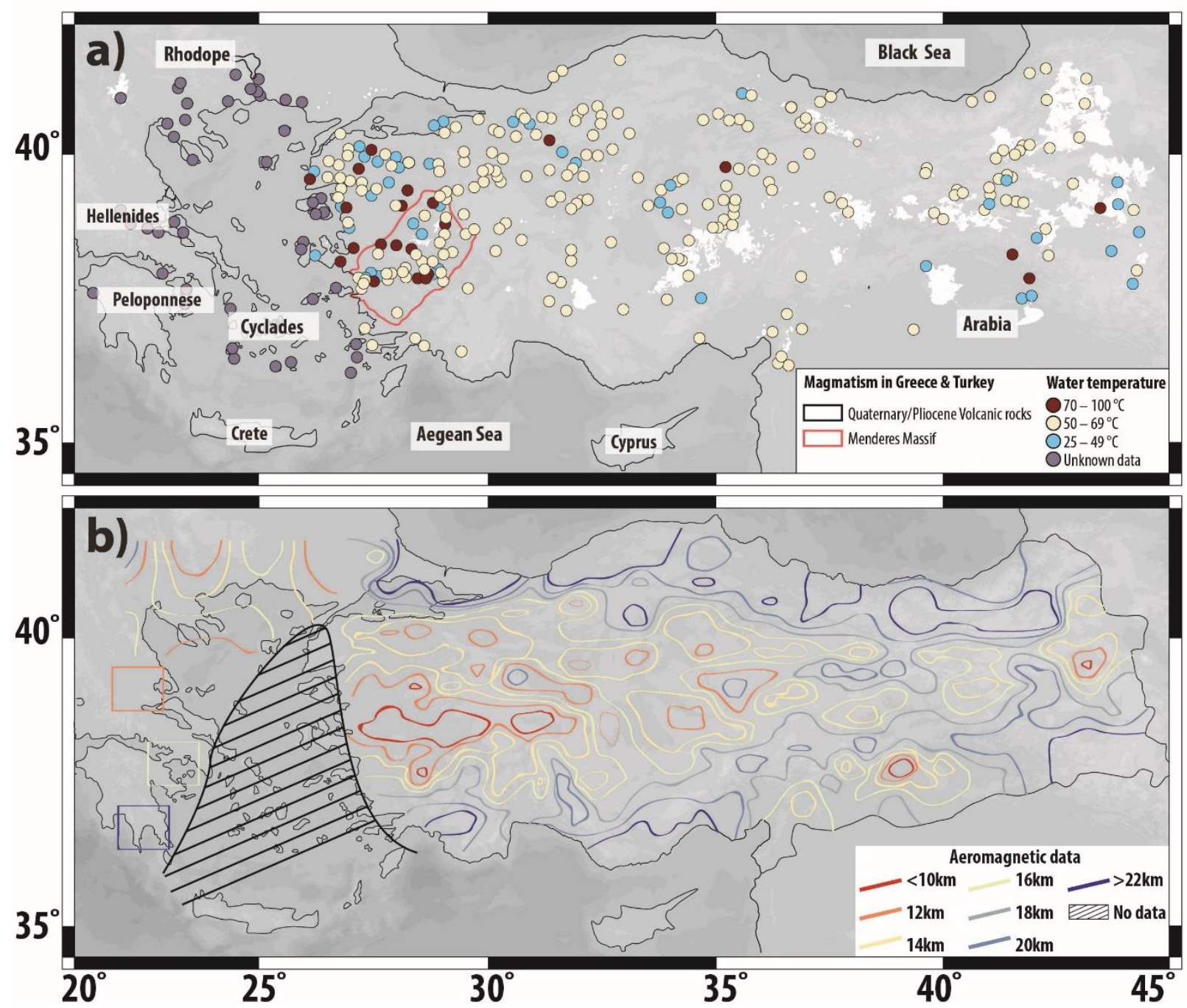

763 Figure S1: Maps of the Aegean-Anatolian region. (a) Geothermal map of eastern Mediterranean

764 region highlighting major thermal occurrences based on a compilation of several data sources

765 (from the MTA (2005); Mendrinos et al. (2010) and Andritsos et al. (2015)), and spatial

766 distribution of Pliocene-Quaternary volcanic rocks (from the geological map of the MTA). (b) 
767 Curie-point depth map from Tselentis (1991); Stampolidis and Tsokas (2002) and Aydin et al. 768 (2005).

769

770

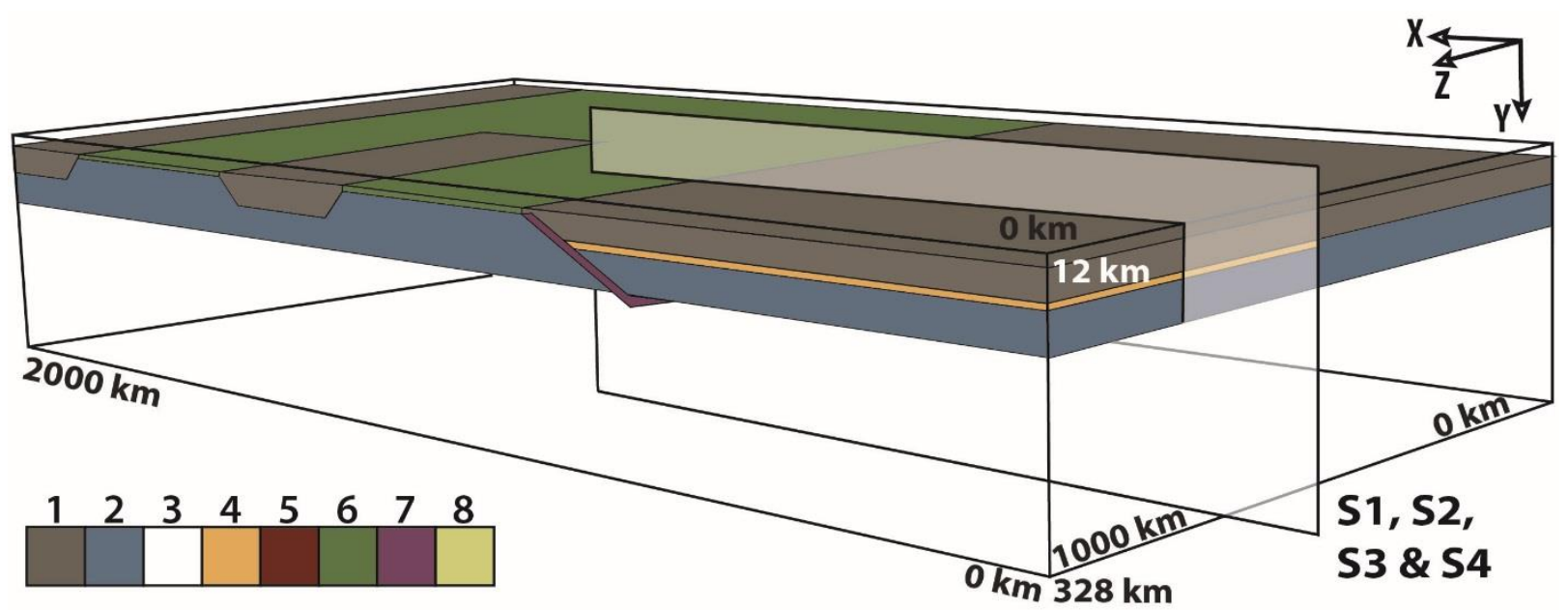

771 Figure S2: Location of videos shown by the vertical cross-section from our reference numerical

772 model. Colours showing different rock types: 1-2-3-4-5-6-7-8 as defined in Figure 3. 


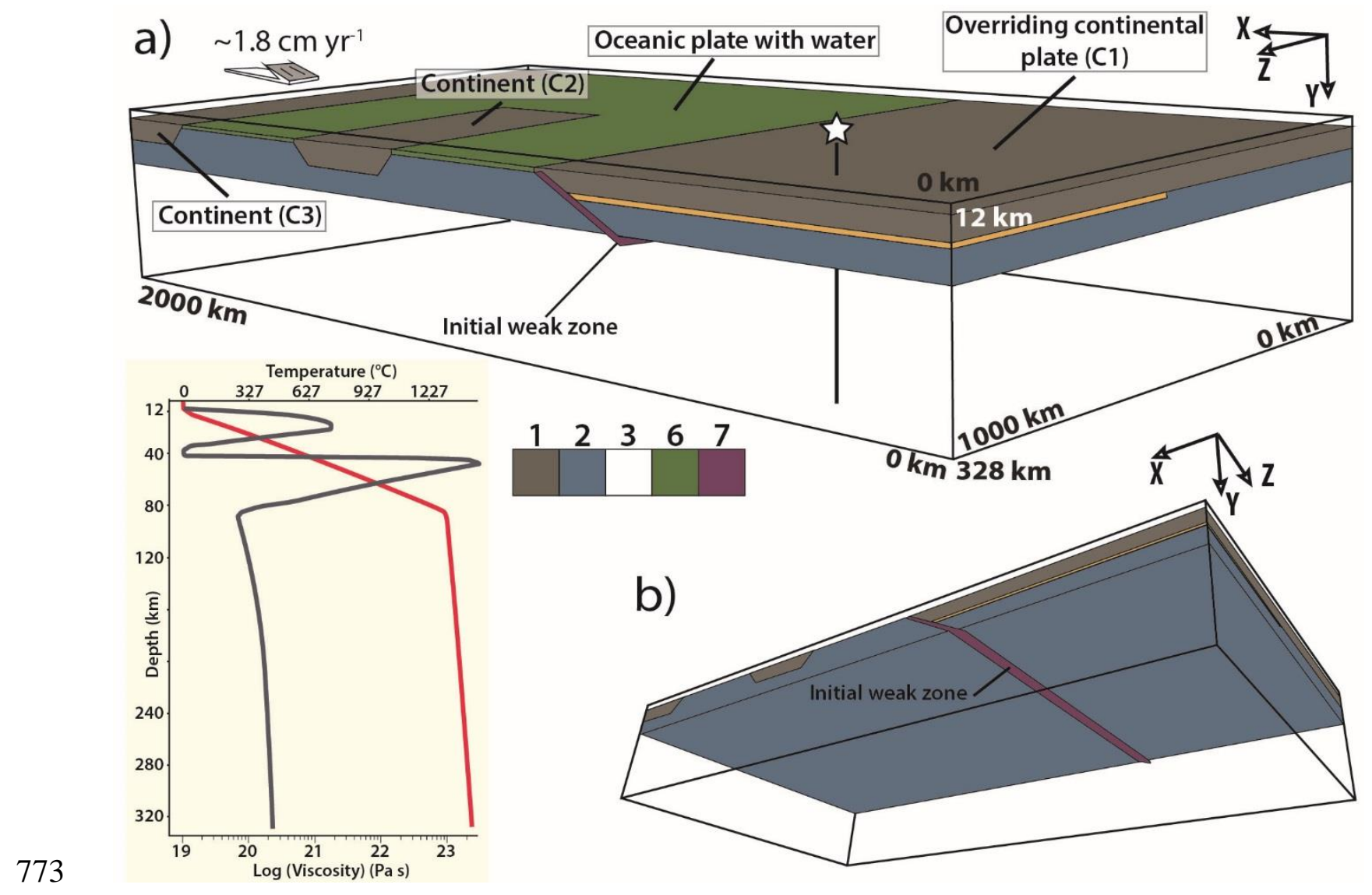

774 Figure S3: Experimental setup without slab tearing. (a) 3D initial model setup where the top layer

775 ("sticky air", $\mathrm{y}<\sim 12 \mathrm{~km}$ ") and the water are cut off for clarity. Colours showing different rock

776 types as defined in Figure 3. Vertical viscosity (grey) and temperature (red) profiles at to, taken

777 at the location shown by the white star. (b) Location of the "weak zone" (i.e.

778 hydrated/serpentinized mantle) into the lithosphere to initialise subduction (z-parallel). 

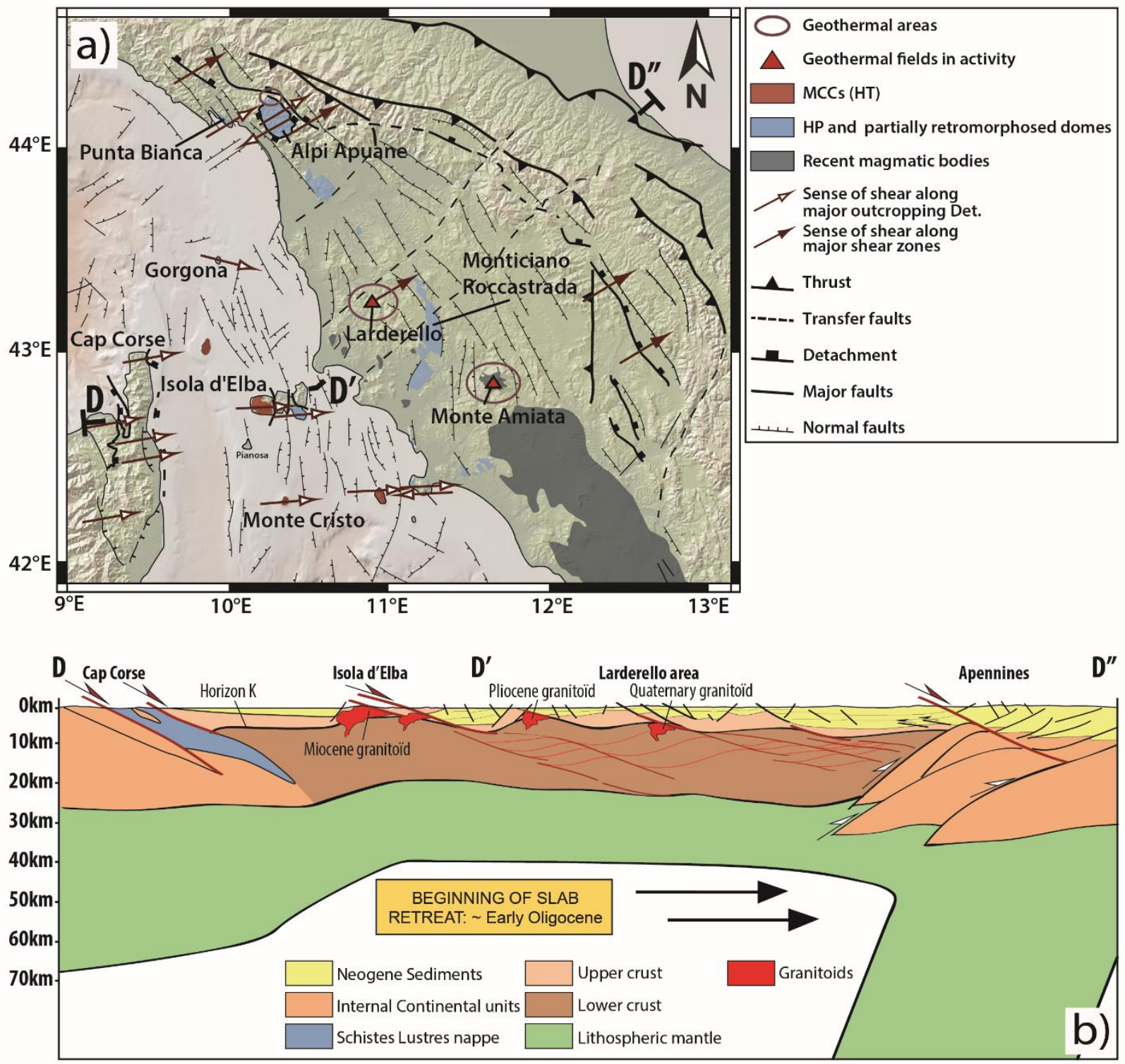

781 Figure S4: Simplified tectonic map showing the main metamorphic core complexes and

782 associated detachments faults. (a) Map of the Northern Tyrrhenian region and Northern

783 Apennines, modified from Jolivet et al. (1998). (b) Simplified cross-sections highlighting slab

784 retreat and formation of crustal detachments.

786 Videos S1 - S4 showing the ascent of partially molten material (the yellowish color), the thermal

787 domes, the composition and the second invariant of the strain rate tensor evolution, respectively. 
788 Note that the location of the modeled arc in our numerical model is the position of mantle 789 upwellings (i.e. molten material) projected at the surface. Even if the distance between arc and

790 trench changes in time and space, note that the distance should be around $100-150 \mathrm{~km}$ from the

791 trench toward the upper plate.

792

793 2. Supplementary materials

794

795

2.1. 3-D numerical approach

796

797 Continuity and momentum equations

798 The code I3ELVIS uses a staggered finite difference scheme combined with the marker-in799 cell technique (Gerya, 2010). Lagrangian advecting markers are thus combined with an immobile

800 Eulerian grid. The incompressible continuity equation describes the conservation of mass during

801 the deformation of a continuous medium (rocks) as:

$802 \operatorname{div}(\vec{v})=0$,

$803 \quad(2)$

804 where $\vec{v}$ is the local velocity and $\operatorname{div}()$ is the divergence operator.

805 The conservation of momentum is obtained through the solution of the Stokes equation:

$806 \frac{\partial \sigma_{i j}^{\prime}}{\partial x_{j}}-\frac{\partial P}{\partial x_{i}}+\rho g_{i}=0$,

$807 \quad(3)$

808 where $i$ and $j$ denote the coordinate indices (i.e. $\mathrm{x}, \mathrm{y}, \mathrm{z}$ ), $\sigma^{\prime}$ is the deviatoric stress tensor, $x_{i}$ and $809 x_{j}$ are the spatial coordinates and $g_{i}$ is the $i^{\text {th }}$ component of the gravity vector $\vec{g}$. 
812 In order to predict changes in temperature due to heat transport, the Lagrangian heat

813 conservation equation is solved, which consider conductive heat transport, as well as internal heat

814 generation:

$815 \rho C_{p} \frac{D T}{D t}=-\frac{\partial q_{i}}{\partial x i}+H$

$816 \quad(4)$

817 where the heat flux vector $\vec{q}$ is related to the temperature gradient in space as:

$818 q_{i}=-k \frac{\partial T}{\partial x_{i}}$.

$819 \quad(5)$

$820 T$ is temperature and $k$ is the thermal conductivity of the material, which depends on pressure $(P)$,

$821 T$, and composition of the material. $C p$ is the isobaric heat capacity, $\frac{D T}{D t}$ is the substantive time

822 derivative of temperature and $H$ is the volumetric heat productions. The latter term includes

823 several types of heat generation/consumption processes:

$824 \quad H=H_{r}+H_{s}+H_{a}$,

$825(6)$

826 where $H_{r}$ is the radiogenic heat production, $H_{s}$ is the shear heating and $H_{a}$ is the adiabatic heat

827 production. $H_{s}$ is related to dissipation of the mechanical energy during irreversible non-elastic

828 (e.g. viscous) deformation. It is calculated as:

$829 H_{s}=\sigma_{i j}^{\prime} \dot{\varepsilon}_{i j}^{\prime}$,

$830 \quad(7)$ 
831 where $\dot{\varepsilon}^{\prime}$ is the strain rate tensors. $H_{a}$ corresponds to heat production related to pressure changes.

832 It is calculated as:

$833 H_{a}=T \alpha \frac{D P}{D t}$,

$834 \quad(8)$

835 where $\frac{D P}{D t}$ is the substantive time derivative of pressure. Advection of temperature is performed

836 by using Lagrangian markers (Gerya, 2010).

838 Viscous rheology of rocks

839 The physical properties of rocks used in our experiments are given in Table 1. Among

840 them, the density of solid rocks depends on $P, T$, and composition. In our experiments, $\rho_{\text {solid }}$ is

841 calculated as follow:

$842 \rho_{\text {solid }}=\rho_{0 \text { solid }}\left[1+\beta\left(P-P_{r}\right)\right] *\left[1-\alpha\left(T-T_{r}\right)\right]$

$843(9)$

844 where $\rho_{0 \text { solid }}$ is the standard density of solid rocks at reference pressure $\operatorname{Pr}\left(10^{5} \mathrm{~Pa}=1 \mathrm{bar}\right)$ and

845 temperature $T_{r}\left(298.15 \mathrm{~K}=25^{\circ} \mathrm{C}\right) ; \alpha$ and $\beta$ are respectively the thermal expansion and

846 compressibility of rock. As density is also modified by phase changes (such as partial melting

847 which is implemented in this code), effective rock density $\rho$ eff is calculated as follow:

$848 \rho_{\text {eff }}=\rho_{\text {solid }}\left(1-M+M \frac{\rho_{\text {omolten }}}{\rho_{\text {osolid }}}\right)$,

849 where $\rho_{\text {Omolten }}$ is the standard density of molten rock, and $M$ is the volumetric melt fraction in

850 partially molten rock (see below for more information). In addition, non-Newtonian visco-plastic

851 rheologies used in our experiments are implemented by both ductile and brittle/plastic 
852 experimentally constrained laws. Effective viscosity for dislocation creep thus depends on the

853 strain rate, pressure and temperature. It is calculated as follow:

$854 \quad \eta_{\text {creep }}=\dot{\varepsilon}_{I I} \frac{1-n}{n} A_{D} \frac{-1}{n} \exp \left(\frac{E+P V}{n R T}\right)$,

$855 \quad(11)$

856 where $\dot{\varepsilon}_{I I}$ is the square root of the second invariant of the strain rate tensor, $R$ is the gas constant,

$857 n$ is the creep exponent, $A_{D}$ is the pre-exponential factor, $E$ is the activation energy) and $V$ is the

858 activation volume. These parameters depend on the applied viscous flow law (i.e. wet quartzite,

859 plagioclase $\left(\mathrm{An}_{75}\right)$, dry olivine and wet olivine flow laws; Table 1) (Ranalli, 1995). This ductile

860 behavior is limited with a brittle/plastic one, implemented by using the Drucker-Prager criterion

$861 \quad \sigma y i e l d$ (i.e. plastic strength) (Ranalli, 1995) as follow:

$862 \quad \eta_{\text {creep }} \leq \frac{\sigma_{y i e l d}}{2 \dot{\varepsilon}_{I I}}$

$863 \quad(12)$

864 where $\sigma y i e l d$ is calculated as:

$865 \sigma_{\text {yield }}=\sigma_{c}+P \sin (\varphi)$

866 where $\sigma_{C}$ is the compressive strength of the rock, $P$ is the dynamic pressure and $\varphi$ is the effective

867 internal friction angle depending on the fluid and melt presence (see details in Gerya and Meilick 868 (2011)).

869

$870 \quad$ Fluid/melt dynamics: example of partial melting

871 In our experiments, partial melting process is also included. For all crustal rocks, the 872 volumetric melt fraction $\left(\mathrm{M}_{0}\right)$ is calculated as follow:

$873 \quad M_{0}=0$ at $T<T_{\text {solidus }}$ 
$874 \quad M_{0}=\frac{T-T_{\text {solidus }}}{T_{\text {liquidus }}-T_{\text {solidus }}}$ at $T_{\text {solidus }}<T<T_{\text {liquidus }}$

$875 \quad(14)$

$876 \quad M_{0}=1$ at $T>T_{\text {liquidus }}$

877 where $M_{0}$ is the volumetric fraction of melt with no previous melt extraction, $T_{\text {solidus }}$ and $T_{\text {liquidus }}$

878 are, respectively, the solidus and liquidus temperatures depending on the pressure and rock

879 composition (Table 1). For the mantle, the degree of partial melting depends on the water

880 content according to the parameterization of Katz et al. (2003). Resulting partially molten

881 rocks can then undergo a succession of melt extraction episodes depending on their melt

882 extraction threshold $M_{\max }$ and non-extractable melt fraction $M_{\min }$, both equal to $1 \%$. Only the

883 exceeding volumetric melt fraction (i.e. > $1 \%$ ) is then extracted from partially molten rocks,

884 thus generating magma markers. For each extraction episode, the melt fraction $M_{\text {ext }}$ recorded in

885 the partially molten rock markers is calculated as:

$886 \quad M_{\text {ext }}=M-M_{\min }$,

$887 \quad(15)$

888 where $\mathrm{M}$ is the volumetric melt fraction in partially molten rock, accounting for previous melt

889 extraction events. It is calculated as:

$890 \quad M=M_{0}-\sum M_{e x t}$,

$891 \quad(16)$

892 where $\Sigma M_{e x t}$ is the total melt fraction from previous extraction episodes. Then, $M$ varies

893 dynamically until remaining solid rock is no longer able to undergo additional partial melting 894 (i.e. $\Sigma M_{\text {ext }}>M_{0}$ ). Magma markers resulting from these extraction episodes are then 895 instantaneously transmitted to the surface as free melt is assumed to propagate upward much 896 faster than rocks deform (Hawkesworth, 1997). 


\begin{tabular}{|c|c|c|c|c|c|c|c|c|c|c|c|c|}
\hline \multirow{2}{*}{ Material } & k & $\mathrm{Hr}$ & $\rho_{0}$ & $\mathrm{C}_{\mathrm{p}}$ & $E_{a}$ & $\mathrm{~V}_{\mathrm{a}}$ & $\alpha$ & $\beta$ & $\mathbf{n}$ & $\eta_{0}$ & Viscous & \\
\hline & 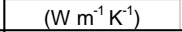 & $\left(\mathrm{mW} \mathrm{m}^{-3}\right)$ & $\left(\mathrm{kg} \mathrm{m}^{-3}\right)$ & $\left(\mathrm{J} \mathrm{kg}^{-1} \mathrm{~K}^{-1}\right)$ & $\left(\mathrm{kg} \mathrm{mol}^{-1}\right)$ & $\left(\mathrm{m}^{3} \mathrm{~mol}^{-1}\right)$ & $\left(K^{-1}\right)$ & $\left(\mathrm{kbar}^{-1}\right)$ & & $\left(\mathrm{Pa}^{\mathrm{n}} \mathrm{s}\right)$ & flow law & $\sin \left(\Phi_{\text {eff }}\right)$ \\
\hline Sticky-air & 20 & 0 & 1 & 100 & 0 & 0 & 0 & 0 & 1 & $1 \times 10^{19}$ & Air & 0 \\
\hline Water & 20 & 0 & 1000 & 3330 & 0 & 0 & 0 & 0 & 1 & $1 \times 10^{19}$ & Water & 0 \\
\hline Sediment & $0.64+807 /(T+77)$ & 2 & 2600 & 1000 & 154 & 8 & $3 \times 10^{-5}$ & $1 \times 10^{-3}$ & 2.3 & $1.97 \times 10^{17}$ & Wet Qz. & 0.15 \\
\hline Cont. Crsut (C1 \& C3) & $0.64+807 /(T+77)$ & 2 & 2750 & 1000 & 154 & 8 & $3 \times 10^{-5}$ & $1 \times 10^{-3}$ & 2.3 & $1.17 \times 10^{17}$ & Wet Qz. & 0.15 \\
\hline Cont. Crsut (2) & $1.18+807 /(T+77)$ & 2 & 2950 & 1000 & 238 & 8 & $3 \times 10^{-5}$ & $1 \times 10^{-3}$ & 3.2 & $4.8 \times 10^{22}$ & Wet Qz. & 0.15 \\
\hline Oc. Crust & $1.18+474 /(T+77)$ & 0.25 & 3000 & 1000 & 238 & 8 & $3 \times 10^{-5}$ & $1 \times 10^{-3}$ & 3.2 & $4.8 \times 10^{22}$ & Wet Qz. & 0.15 \\
\hline Mantle & $0.73+1293 /(T+77)$ & 0.02 & 3300 & 1000 & 532 & 8 & $3 \times 10^{-5}$ & $1 \times 10^{-3}$ & 3.5 & $3.98 \times 10^{16}$ & Dry OI. & 0.6 \\
\hline Weak zone & $0.73+1293 /(T+77)$ & 0.05 & 3300 & 1000 & 47 & 8 & $3 \times 10^{-5}$ & $1 \times 10^{-3}$ & 4 & $5 \times 10^{20}$ & Wet Ol. & 0 \\
\hline
\end{tabular}

898 Table 1: Material properties used in the numerical experiments. $\mathrm{k}$ denotes the thermal

899 conductivity, $\mathrm{H}_{\mathrm{r}}$ is the radiogenic heat production, $\rho_{0}$ is the density, $\mathrm{C}_{\mathrm{p}}$ is the specific heat

900 capacity, $\mathrm{E}_{\mathrm{a}}$ is the activation energy, $\mathrm{V}_{\mathrm{a}}$ is the activation volume, $\alpha$ is the thermal expansion, $\beta$ is

901 the compressibility coefficient, $\mathrm{n}$ is the stress exponent, $\eta_{0}$ is the reference viscosity and $\Phi_{\text {eff }}$ is

902 the effective internal friction angle. Qz. and Ol. correspond to the abbreviations of Quartzite and

903 Olivine.

904

905

\subsection{2-D numerical approach}

906

907

The numerical model presented in Figures 7 and 8 has been built on the same basis as those

908 published by Guillou-Frottier et al. (2013). Darcy's law is coupled with the heat equation in a

909 porous medium and with mass conservation. We have used the Comsol Multiphysics ${ }^{\mathrm{TM}}$ software, $^{-}$

910 where temperature-dependent properties can be easily implemented. Benchmark experiments

911 have already been performed and published (Garibaldi et al., 2010).

912 The numerical mesh consisted in more than 32,000 triangles, with a maximum size of $40 \mathrm{~m}$

913 within the detachment. Petrophysical properties are given in Table 2. Fluid density law was

914 chosen to fit the experimental data for pure water between 20 and $350{ }^{\circ} \mathrm{C}$ :

$915 \rho_{L}(T)=1002.4-0.1905 * T-0.0025 * T^{2}$

$916 \quad(17)$ 
917 where $\mathrm{T}$ is temperature in ${ }^{\circ} \mathrm{C}$ and $\rho_{L}$ the fluid density in $\mathrm{kg} \mathrm{m}^{-3}$. For temperature greater than

$918350^{\circ} \mathrm{C}$, fluid density is assigned a constant value of $630 \mathrm{~kg} \mathrm{~m}^{-3}$. This choice has no fundamental

919 consequences on the results since at these high temperatures, fluid is located at depth greater than

$9205 \mathrm{~km}$, where permeability does not allow fluid circulation. For the fluid dynamic viscosity, the

921 law used has been written as:

$922 \mu(T)=2.41410^{-5} \times \exp \left(\frac{570}{T+133}\right)$

$923(18)$

924 where $\mathrm{T}$ is in ${ }^{\circ} \mathrm{C}$ and dynamic viscosity $\mu$ is in Pa s.

925 The initial pressure field increases linearly with depth. The initial temperature field is 926 computed in a conductive regime, such that the surface temperature is $20^{\circ} \mathrm{C}$ and the bottom of 927 the box (10 km depth) is close to $500{ }^{\circ} \mathrm{C}$, as it is suggested by Aydin et al. (2005). To reach a 928 temperature around $\sim 500{ }^{\circ} \mathrm{C}$ at a depth of $10 \mathrm{~km}$, a basal heat flow of $120 \mathrm{~mW} \mathrm{~m}$ is imposed 929 during the transient behaviour. At $t>0$, permeability values (see Table 2) are affected to the two 930 units, and transient evolution of temperature and velocity fields are recorded. The chosen 931 permeability law accounts for depth-dependence reaching a low value $\left(\sim 10^{-18} \mathrm{~m}^{2}\right)$ at the brittle932 ductile transition, as suggested by Violay et al. (2017).

\begin{tabular}{|c|cc|}
\cline { 2 - 3 } \multicolumn{1}{c|}{} & Basement & Detachment \\
\hline Eq. thermal conductivity(*) & 2.8 & 1.6 \\
Porosity $(\%)$ & 5 & 30 \\
Permeability $(* *)\left(\mathbf{m}^{2}\right)$ & {$\left[10^{-17}-10^{-14}\right] \exp ((\mathrm{z}-2000) / 1000)$} & {$\left[10^{-17}-10^{-14}\right]$} \\
\hline
\end{tabular}


\begin{tabular}{|l|cc|} 
Heat production $\left(\mu \mathbf{W} . \mathbf{m}^{-3}\right)$ & & 0 \\
& 1.0 & 0 \\
\hline
\end{tabular}

933 Table 2: Material properties used in the numerical experiments. (*) the equivalent thermal

934 conductivity accounts for solid matrix and fluid-filled pores. (**) permeability decreases

935 exponentially with depth, except in the detachment.

936

937 REFERENCES

938

939 Andritsos, N., Dalambakis, P., Arvanitis, A., Papachristou, M., \& Fytikas, M. (2015).

940 Geothermal developments in Greece-Country update 2010-2014. In Proceedings World

941 Geothermal Congress 2015 (pp. 19-24).

942 Aydın, İ., Karat, H. İ., \& Koçak, A. (2005). Curie-point depth map of Turkey. Geophysical

943 Journal International, 162(2), 633-640.

944 Garibaldi, C., Guillou-Frottier, L., Lardeaux, J.M., Bonté, D., Lopez, S., Bouchot, V., \& P.,

945 Ledru. (2010). Thermal anomalies and geological structures in the Provence basin :

946 implications for hydrothermal circulations at depth. Bulletin de la Société Géologique de

$947 \quad$ France 181, 363-376.

948 Gerya, T. V., \& F. I. Meilick (2011). Geodynamic regimes of subduction under an active

949 margin: effects of rheological weakening by fluids and melts, J. Metamorph. Geol., 29(1),

950 7-31, doi:10.1111/j.1525-1314.2010.00904.x.

951 Guillou-Frottier, L., Carrè, C., Bourgine, B., Bouchot, V., \& A., Genter. (2013). Structure of

952 hydrothermal convection in the Upper Rhine Graben as inferred from corrected 
954 Geothermal Research, 256, 29-49.

955 Hawkesworth, C. J. (1997). U-Th Isotopes in Arc Magmas: Implications for Element Transfer

956 from the Subducted Crust, Science, 276(5312), 551-555,

957 doi:10.1126/science.276.5312.551.

958 Katz, R. F., Spiegelman, M., \& Langmuir, C. H. (2003). A new parameterization of hydrous

959 mantle melting. Geochemistry, Geophysics, Geosystems, 4(9).

960 Mendrinos, D., Choropanitis, I., Polyzou, O., \& Karytsas, C. (2010). Exploring for geothermal 961 resources in Greece. Geothermics, 39(1), 124-137.

962 MTA, Geothermal Energy Projects Reports (1970-2008).

963 Ranalli, G. (1995). Rheology of the Earth, Chapman \& Hall., London, UK.

964 Stampolidis, A., \& Tsokas, G. N. (2002). Curie point depths of Macedonia and Thrace, N.

965 Greece. Pure and Applied Geophysics, 159(11), 2659-2671.

966 Tselentis, G. A. (1991). An attempt to define Curie point depths in Greece from aeromagnetic 967 and heat flow data. pure and applied geophysics, 136(1), 87-101.

968 Violay, M., Heap, M. J., Acosta, M., \& Madonna, C. (2017). Porosity evolution at the brittle969 ductile transition in the continental crust: Implications for deep hydro-geothermal $970 \quad$ circulation. Scientific reports, 7(1), 7705.

971

972 